Article

\title{
Peucedanum ostruthium Inhibits E-Selectin and VCAM-1 Expression in Endothelial Cells through Interference with NF- $\kappa$ B Signaling
}

\author{
Christoph Lammel ${ }^{1}$, Julia Zwirchmayr ${ }^{2}{ }^{(D}$, Jaqueline Seigner ${ }^{1}\left(\mathbb{D}\right.$, Judith M. Rollinger ${ }^{2, *}$ and \\ Rainer de Martin ${ }^{1}$ \\ 1 Department of Vascular Biology and Thrombosis Research, Medical University of Vienna, \\ Schwarzspanierstaße 17, 1090 Vienna, Austria; christoph.lammel@gmx.at (C.L.); \\ jacqueline.seigner@meduniwien.ac.at (J.S.); rainer.demartin@meduniwien.ac.at (R.d.M.) \\ 2 Department of Pharmacognosy, Faculty of Life Sciences, University of Vienna, Althanstraße 14, 1090 Vienna, \\ Austria; julia.zwirchmayr@univie.ac.at \\ * Correspondence: judith.rollinger@univie.ac.at; Tel.: +43-1-4277-55255; Fax: +43-1-4277-855255
}

Received: 5 June 2020; Accepted: 18 August 2020; Published: 21 August 2020

check for updates

\begin{abstract}
Twenty natural remedies traditionally used against different inflammatory diseases were probed for their potential to suppress the expression of the inflammatory markers E-selectin and VCAM-1 in a model system of IL-1 stimulated human umbilical vein endothelial cells (HUVEC). One third of the tested extracts showed in vitro inhibitory effects comparable to the positive control oxozeaenol, an inhibitor of TAK1. Among them, the extract derived from the roots and rhizomes of Peucedanum ostruthium (i.e., Radix Imperatoriae), also known as masterwort, showed a pronounced and dose-dependent inhibitory effect. Reporter gene analysis demonstrated that inhibition takes place on the transcriptional level and involves the transcription factor NF- $\mathrm{KB}$. A more detailed analysis revealed that the $P$. ostruthium extract (PO) affected the phosphorylation, degradation, and resynthesis of $I \kappa B \alpha$, the activation of IKKs, and the nuclear translocation of the NF- $\kappa B$ subunit RelA. Strikingly, early effects on this pathway were less affected as compared to later ones, suggesting that PO may act on mechanism(s) that are downstream of nuclear translocation. As the majority of $\operatorname{cognate} \mathrm{NF}-\mathrm{kB}$ inhibitors affect upstream events such as IKK2, these findings could indicate the existence of targetable signaling events at later stages of NF- $\kappa B$ activation.
\end{abstract}

Keywords: Peucedanum ostruthium; masterwort; inflammation; endothelial cells; E-selectin; VCAM-1; NF-кB

\section{Introduction}

The inflammatory reaction is a common feature of several diseases, including cardiovascular, gastrointestinal, and neurodegenerative, as well as joint and skin disorders. Inflammatory mediators such as IL-1 and TNF or bacterial LPS evoke the expression of a complex set of genes in the endothelium that encode, e.g., chemoattractants and adhesion molecules, a pre-requisite for the adherence and transmigration of immune cells through the vascular wall into the underlying tissue, where they migrate towards the site of injury. However, they also fulfill other functions that are related to proliferation, cell and tissue dynamics, metabolism, survival and apoptosis [1]. Examples of induced genes include the adhesion molecules E-selectin, ICAM-1, VCAM-1, the cytokines IL-1, IL-6, IL-8, chemokines and their receptors, cyclooxygenase, and anti-apoptotic proteins of the IAP family and A20.

The transcription factor NF- $\mathrm{KB}$ has been demonstrated to play a major role in the expression of many of these genes, and inhibition of its activation was shown to prevent or at least attenuate pro-inflammatory gene expression. NF- $\kappa B$ comprises a family of five members that can form homo- 
and heterodimers, the most common one being the RelA/p50 heterodimer. It is held in the cytoplasm through interaction with one of its inhibitors, Iк $\mathrm{B} \alpha$, which prevents its nuclear translocation (for review see [2,3]). Following stimulation of endothelial cells with IL-1, TNF or LPS, signals are generated that proceed in part via receptor-specific adapter molecules towards a common kinase complex consisting of IKK1, IKK2 and the regulatory subunit NEMO/IKK $\gamma$. Thereby, IKK2 is mainly responsible for the phosphorylation of $I_{\kappa} B \alpha$, a signal that, in turn, leads to its K48-linked ubiquitination and proteasomal degradation. Subsequently, NF- $\mathrm{kB}$ is free to translocate to the nucleus, bind to its respective binding sites in the promoter region of the genes mentioned above, and direct their transcription. Several feedback mechanisms, including NF-kB-dependent IкB $\alpha$ resynthesis, A20 expression, or IKK2 hyper-phosphorylation, ensure a timely shut-down of NF- $\mathrm{KB}$ activity and thereby the transient nature of its activation [4,5]. Last not least, regulatory steps affecting the transactivation domain, miRNAs, as well as cross-talk with other pathways, can modulate NF-kB activity [6-8].

Despite the availability of numerous steroidal and non-steroidal anti-inflammatory drugs limitations to their use sometimes occur in clinical settings, e.g., in the treatment of chronic diseases, calling for a quest for novel lead structures. Nature has been a rich source of such structures for all kind of maladies, including inflammation [9], and treatment is often backed by long-standing traditional use. A previous investigation on 71 Austrian herbal drugs identified in vitro anti-inflammatory extracts in the so-called "VOLKSMED" database [10] and revealed inter alia the root extract of Peucedanum ostruthium (PO) as a promising herbal remedy for a closer investigation. Here, we report the screening of 20 extracts from traditionally used herbal and fungal materials as well as the in-depth characterization of $\mathrm{PO}$, and provide mechanistic insight into its mode of action.

\section{Materials and Methods}

\subsection{Preparation of Herbal/Fungal Extracts}

Plant and mushroom materials were obtained from different suppliers. Detailed information on the used plant/fungal species, organ and the respective extraction solvents are given in Table 1 . Voucher specimens are deposited at the Department of Pharmacognosy, University of Vienna, Austria, if not otherwise indicated. Small-scale extracts were prepared according to the protocol for the generation of lead-like enhanced (LLE) extracts as previously described in [11] adapted from [12], if not otherwise indicated (Table 1). Briefly, $0.3 \mathrm{~g}$ of dried, pulverized herbal or fungal material was defatted with $5 \mathrm{~mL} n$-hexane (VWR International, Radnor, PA, USA; AnalaR NORMAPUR ACS, $\geq 95 \%$ ). The remaining material was extracted successively with $7 \mathrm{~mL}$ dichloromethane $\left(\mathrm{CH}_{2} \mathrm{Cl}_{2}\right.$; VWR International; GPR RECTAPUR, $\left.\geq 99 \%\right)$ and $13 \mathrm{~mL}$ methanol $(\mathrm{MeOH}$, AnalaR NORMAPUR ACS, $\geq 99.8 \%$ ) at room temperature under sonication for $15 \mathrm{~min}$. The extracts were filtered, combined and dried under vacuum to obtain lead-like enhanced extracts without tannin depletion (LLE w/o TD). Tannin-rich extracts were further subjected to tannin depletion to avoid any unspecific assay interferences. Protocols for the generation of tannin-depleted samples have been described previously $[12,13]$ and successfully applied in several studies [11,14-16]. For this process, the dried $\mathrm{CH}_{2} \mathrm{Cl}_{2}-\mathrm{MeOH}$ extracts were restored in 4-mL MeOH, loaded onto a 3-mL solid-phase extraction cartridge (Phenomenex, Torrance, CA, USA; AH0-7001) filled with polyamide gel (Carl Roth, Karlsruhe, Germany; CC-6; $900 \mathrm{mg}$ ) and washed two times with MeOH. The obtained tannin-depleted samples were dried under vacuum to deliver the final extract (LLE). Dried extracts were dissolved in DMSO (Carl Roth; Rotipuran $\geq 99.8 \%$, p.a.) to a final concentration of $10 \mathrm{mg} / \mathrm{mL}$. Samples were stored at $-20^{\circ} \mathrm{C}$ until used. 
Table 1. Information on used natural materials and extracts (LLE, lead-like enhanced extracts; LLE w/o TD, lead-like enhanced extracts without tannin depletion).

\begin{tabular}{|c|c|c|c|c|c|}
\hline Species & Family & Organ & Provider/Collection Site & Voucher Specimen/Charge Number & Used Extract \\
\hline Aquilegia vulgaris L. & Ranunculaceae & herb & Padma AG, Wetzikon, Switzerland & Ch.Nr.: 21290300 & LLE \\
\hline Azadirachta indica A.Juss. & Meliaceae & fruits & Padma AG, Wetzikon, Switzerland & JR-20150615-A1 Ch.Nr.: 2021108301 & LLE \\
\hline Burkea africana Hook. & Leguminosae & bark/heart-wood & Northwest of Zeerust, South Africa & Voucher no 5858 [14] & $\begin{array}{c}\text { Ethanol (EtOH) } \\
\text { extract }\end{array}$ \\
\hline $\begin{array}{l}\text { Capsella bursa-pastoris (L.) } \\
\text { Medik. }\end{array}$ & Brassicaceae & herb & $\begin{array}{l}\text { Kottas Pharma GmbH, } \\
\text { Vienna, Austria }\end{array}$ & Ch.Nr.: 1223296 & $\mathrm{MeOH}$ \\
\hline $\begin{array}{l}\text { Elettaria cardamomum (L.) } \\
\text { Maton }\end{array}$ & Zingiberaceae & fruits & Padma AG, Wetzikon, Switzerland & Ch.Nr.: W17201998 & LLE w/o TD \\
\hline Euphrasia officinalis L. & Orobanchaceae & herb & $\begin{array}{l}\text { Kottas Pharma GmbH, } \\
\text { Vienna, Austria }\end{array}$ & JR-20090625-A1 Ch.Nr.: KLA90309 & LLE \\
\hline $\begin{array}{c}\text { Fomitopsis pinicola (Sw.) P. } \\
\text { Karst. (strain 10) }\end{array}$ & Fomitopsidaceae & fruit body & $\begin{array}{l}\text { Viggartal, Ellbögen, Austria (grown } \\
\text { on dead spruce trunk); Ursula } \\
\text { Peintner }\end{array}$ & FompinE0010 & LLE w/o TD \\
\hline $\begin{array}{c}\text { Forsythia suspensa (Thunb.) } \\
\text { Vahl }\end{array}$ & Oleaceae & fruits & $\begin{array}{l}\text { Plantasia GmbH, Oberndorf bei } \\
\text { Salzburg, Austria }\end{array}$ & Ch.Nr.: 020410 & LLE \\
\hline $\begin{array}{c}\text { Gloeophyllum odoratum } \\
\text { (Wulfen) Imazeki (strain 54) }\end{array}$ & Gloeophyllaceae & fruit body & $\begin{array}{l}\text { Oberperfuss, Austria (grown on } \\
\text { spruce) Ursula Peintner }\end{array}$ & JR-20140310-A1 GloodoE0054 & EtOH extract [17] \\
\hline Humulus lupulus L. & Cannabaceae & flower & $\begin{array}{c}\text { Kottas Pharma GmbH, Vienna, } \\
\text { Austria }\end{array}$ & Ch.Nr.: W12203440 & $\mathrm{CH}_{2} \mathrm{Cl}_{2}$ \\
\hline Lactuca sativa $\mathrm{L}$. & Compositae & leaves & Padma AG, Wetzikon, Switzerland & Ch.Nr.: 21400300 & LLE \\
\hline Morus alba L. & Moraceae & root bark & $\begin{array}{c}\text { Plantasia GmbH, Oberndorf bei } \\
\text { Salzburg, Austria }\end{array}$ & Ch.Nr.: 710797 & LLE \\
\hline $\begin{array}{l}\text { Peucedanum ostruthium (L.) } \\
\text { W.D.J.Koch }\end{array}$ & Apiaceae & roots/rhizom & Birgitzköpfl, Axamer Lizum, Austria & JR-20120814-A1 (small scale extract) & LLE \\
\hline $\begin{array}{l}\text { Peucedanum ostruthium (L.) } \\
\text { W.D.J.Koch }\end{array}$ & Apiaceae & roots/rhizom & $\begin{array}{l}\text { Kottas Pharma GmbH, } \\
\text { Vienna, Austria }\end{array}$ & $\begin{array}{l}\text { JR-20180119-A2 Ch.Nr.: P17301770 } \\
\text { (large scale extract) }\end{array}$ & LLE w/o TD [18] \\
\hline Pimenta dioica (L.) Merr. & Myrtaceae & fruits & Padma AG, Wetzikon, Switzerland & JR-20150615-A4 Ch.Nr.: 21362100 & LLE \\
\hline
\end{tabular}


Table 1. Cont.

\begin{tabular}{|c|c|c|c|c|c|}
\hline Species & Family & Organ & Provider/Collection Site & Voucher Specimen/Charge Number & Used Extract \\
\hline $\begin{array}{c}\text { Piptoporus betulinus (Bull.) P. } \\
\text { Karst. (strain 39) }\end{array}$ & Fomitopsida-ceae & fruit body & $\begin{array}{l}\text { Vahrn bei Brixen, Italy, grown on } \\
\text { birch, Ursula Peintner }\end{array}$ & PipbetE0039 & LLE w/o TD \\
\hline Plantago lanceolate $\mathrm{L}$. & Plantaginaceae & herb & Padma AG, Wetzikon, Switzerland & Ch.Nr.: 21327101 & LLE \\
\hline Potentilla aurea $\mathrm{L}$. & Rosaceae & herb & Padma AG, Wetzikon, Switzerland & JR-20150615-A3 Ch.Nr.: 21161301 & LLE \\
\hline Pterocarpus santalinus L.f. & Leguminosae & wood & Padma AG, Wetzikorn, Switzerland & JR-20190315-A1 Ch.Nr.: P16301836 & LLE \\
\hline Sida cordifolia $\mathrm{L}$. & Malvaceae & herb & Padma AG, Wetzikon, Switzerland & JR-20150615-A2 Ch.Nr.: 20981300 & LLE \\
\hline Verbena officinalis L. & Verbenaceae & herb & Ehnbach-klamm, Zirl, Austria & JR-20120801-A12 & LLE \\
\hline
\end{tabular}




\subsection{Cell Culture}

Human endothelial cells (HUVEC) were isolated from the veins of umbilical cords as described previously [19], and maintained in M199 medium (Lonza, Basel, Switzerland, \#12-119F) supplemented with 20\% FCS (Sigma, St. Louis, MO, USA, \#F6765), 2 mM L-glutamine (Sigma; \#G7513), penicillin (100 units/mL), streptomycin $(100 \mu \mathrm{g} / \mathrm{mL})$, (Pen-Strep, Lonza, Basel, Switzerland, \#DE17-602E), 5 units/mL heparin, and $25 \mu \mathrm{g} / \mathrm{mL}$ ECGS (Promocell, Heidelberg, Germany, ECGS/Heparin \#C-30140). For experiments, post-confluent cells of passage no greater than 5 were used.

\subsection{Antibodies and Reagents}

Antibodies were obtained from the following suppliers and used at the respective dilutions: IкB $\alpha$ (Cell Signaling, Frankfurt, Germany, \#9241; 1:1000), phospho-IкB $\alpha$ (Cell Signaling, \#2859), IKK2 (Cell Signaling, \#8943), phospho-IKK1/2 (Cell Signaling, \#2694), B-actin (Santa Cruz, Heidelberg, Germany, \#sc-1616), and NF-kB p65 (Santa Cruz \#sc-372). As secondary antibodies, goat anti-mouse IgG (HL) cross-adsorbed secondary antibody, HRP (Invitrogen, Carlsbad, CA, USA, \#31432), donkey anti-rabbit IgG HRP-linked whole antibody (Sigma, \#GENA934), and goat anti-rabbit IgG (HL; highly cross-adsorbed secondary antibody) conjugates with Alexa Fluor 488 (Invitrogen, \#A32723) were used. The TAK1 inhibitor (5Z)-7-oxozeaenol: (8-(5-chloro-2-(4-methylpiperazin-1-yl) isonicotinamido)-1-(4-fluorophenyl)-4,5-dihydro-1H-benzo [g] indazole-3-carboxamide was obtained from Sigma (\#499610). Recombinant human IL-1ß was from R\&D Systems, Minneapolis, MN, USA (\#201-LB).

\subsection{Cytotoxicity Assays}

HUVECs were incubated for $4 \mathrm{~h}$ with different concentrations of PO $(50,25,12.5 \mu \mathrm{g} / \mathrm{mL})$, and the CellTox Green Cytotoxicity Assay (Promega, Madison, WI, USA, \#G8741) was performed according to the manufacturer's recommendations. Cytotoxicity was judged by morphological examination.

\subsection{Real-Time PCR}

Total RNA was isolated using the PeqGold Total RNA Isolation Kit (VWR International, Radnor, USA, \#732-2868) according to the manufacturer's instructions. A total of $1 \mu \mathrm{g}$ RNA was reverse-transcribed using random hexamers (Fisher Scientific, Schwerte, Germany; \#SO142) and murine leukemia virus reverse transcriptase (Fisher Scientific, \#10338842). Primers were designed using the software "Primer3", sequences are given in Table S2 (Supplementary Materials). Real-time PCR was performed with the SsoAdvanced Universal SYBR Green Supermix (BioRad, Vienna, Austria, \#1725272) using the StepOnePlus instrument (Applied Biosystems, Foster City, CA, USA), and relative mRNA expression normalized to GAPDH. Fold changes in mRNA expression were calculated according to the 2- $\Delta \Delta \mathrm{Ct}$ method. Results are shown as mean fold induction of averaged $\mathrm{Ct}$-values of triplicates.

\subsection{Cell ELISA}

HUVECs were grown to post-confluency in 96-well plates, pre-treated for $30 \mathrm{~min}$ with various concentrations of the generated extracts as indicated in Figure 1, and then stimulated with IL-1B $(5 \mathrm{ng} / \mathrm{mL})$. Experiments were performed in triplicate. After $4 \mathrm{~h}$, cells were fixed and stained for E-selectin as described previously [20]. 

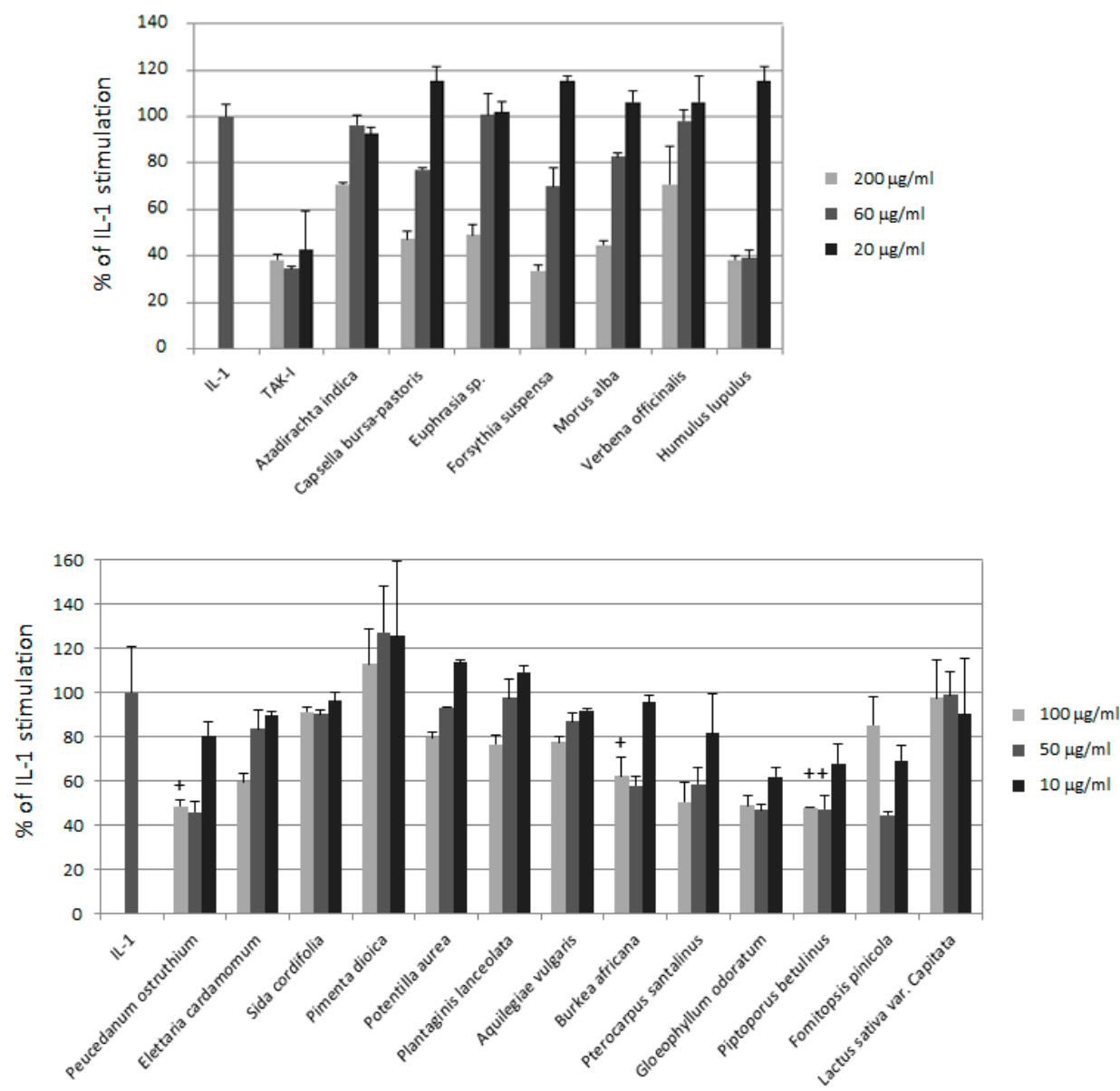

Figure 1. Inhibition of E-selectin expression by herbal and fungal extracts. Experiments were performed in two separate sets (upper and lower panel). HUVECs were pre-incubated for $30 \mathrm{~min}$ with different concentrations of extracts as indicated, stimulated with $5 \mathrm{ng} / \mathrm{mL}$ IL- 1 for $4 \mathrm{~h}$ and analyzed by cell ELISA. The TAK inhibitor (TAK-I) was used as positive control at 10, 5, $2.5 \mu \mathrm{M}$. Relative levels of E-selectin as compared to IL-1 alone are shown. Samples marked with an "+" indicates apparent cytotoxicity as judged by morphological examination.

\subsection{Western Blotting}

Post-confluent HUVEC grown in 6-well plates were pre-incubated for $30 \mathrm{~min}$ with $50 \mu \mathrm{g} / \mathrm{mL} \mathrm{PO}$, stimulated with IL-1ß (5 ng/mL) for different periods of time $(0,10,30,90 \mathrm{~min})$ and lysed in Laemmli buffer. Western blotting for IKB $\alpha$, IKK2, their phosphorylated forms, as well as $\beta$-actin, was done as described [21]. Densitometric analysis was done with Image J.

\subsection{Transfection and Reporter Gene Assays}

HUVEC were grown as described above and transfected with pNL3.2.NF-KB-RE (Promega) and pmaxGFP (Amaxa/Origene, Rockville, MD, USA) by electroporation using a BioRad Gene Pulser with the settings $200 \mathrm{~V} / 960 \mu \mathrm{F}$. Then, $5 \times 10^{6}$ cells were electroporated in $400 \mu \mathrm{L}$ RPMI medium in $0.4 \mathrm{~cm}$ cuvettes with a total of $10 \mu \mathrm{g}$ plasmid DNA. Cells were seeded into 6-well plates and grown for two days before stimulation. Luciferase levels were analyzed using the NanoGlo Luciferase Assay (Promega, \#N1110) according to the manufacturer's protocol and normalized to EGFP fluorescence.

\subsection{Immunofluorescence Microscopy}

Postconfluent HUVECs cultured on fibronectin-coated glass coverslips were treated with $50 \mathrm{ng} / \mathrm{mL}$ PO for $30 \mathrm{~min}$ prior to stimulation with $5 \mathrm{ng} / \mathrm{mL}$ IL-1ß. At the indicated timepoints, cells were fixed 
for 15 min with $4 \%$ paraformaldehyde (Sigma, \#158127), permeabilized for 30 min with $0.1 \%$ Triton X-100 (Sigma, \#93443), washed with PBS and finally blocked for one hour with 3\% BSA-TBS-T. For immunostaining, rabbit polyclonal anti-p65 antibody (Santa Cruz, \#sc-372) was used (1:500) with a secondary antibody, Alexa-Fluor 488-conjugated goat anti-rabbit IgG (Invitrogen, \#A32723) at 1:1000. Cells were counterstained for 15 min with Alexa Fluor 568 phalloidin (Invitrogen, \# A12380 1:1000) and 5 min with 4',6-Diamidino-2-phenylindole (DAPI, Life Technologies, Carlsbad, CA, USA, \#62247; 1:10000). Samples were examined with an Olympus IX71 microscope with a 20x/0.75 UPlanSApo objective. Images were processed with Image J software.

\subsection{Ultra Performance Liquid Chromatography}

UPLC analysis was performed on a Waters Acquity UPLC system (Waters Corporation, Milford, MA, USA; H-class) equipped with a quaternary solvent manager, a sample manager, a column manager, an isocratic solvent manager, a photodiode array (PDA) detector, an evaporative light scattering detector (ELSD), and a fraction collector. A Waters Acquity UPLC BEH Phenyl column $(1.7 \mu \mathrm{m}$, $2.1 \times 100 \mathrm{~mm}$ ) was used for analytical experiments. Data acquisition and processing were conducted using the operating software Waters Empower 3. PO was chromatographed over UPLC using a binary mobile phase system consisting of (A) $\mathrm{H} 2 \mathrm{O}$ and (B) $\mathrm{CH}_{3} \mathrm{CN}$. The gradient was from $13-98 \% \mathrm{~B}$ in $12 \mathrm{~min}$ followed by 5 min re-equilibration. Method in detail: $13 \%$ B for $0.5 \mathrm{~min}, 13-18 \%$ B in $0.5 \mathrm{~min}, 18-45 \%$ $\mathrm{B}$ in $1 \mathrm{~min}$, isocratic $45 \% \mathrm{~B}$ for $1.7 \mathrm{~min}, 45-73 \% \mathrm{~B}$ in $2.8 \mathrm{~min}, 73-98 \% \mathrm{~B}$ in $0.3 \mathrm{~min}$, isocratic $98 \%$ B for $5 \mathrm{~min}, 98-13 \% \mathrm{~B}$ in $0.1 \mathrm{~min}$, isocratic $13 \% \mathrm{~B}$ for $0.1 \mathrm{~min}$; Conditions: temperature, $40{ }^{\circ} \mathrm{C}$; flow rate, $0.300 \mathrm{~mL} / \mathrm{min}$; injection volume, $1 \mu \mathrm{L}$. Detection of compounds using PDA and ELSD. PDA conditions: $210 \mathrm{~nm}$ and full range spectra $192-400 \mathrm{~nm}$. Further, the UPLC system was coupled to an Acquity QDa mass detector with an electrospray ionization source. An isocratic solvent manager was used as a make-up pump and positioned before the mass detector. The main flow stream was then split (1:10) and compounds detected in the positive ionization mode. (Ultrahigh-)gradient grade solvents from VWR Chemicals were used for all analytical experiments.

\subsection{Statistical Significance Calculations}

Differences between samples were analyzed by Ordinary one-way ANOVA with Dunnett's multiple comparisons test using Graph Pad Prism software, San Diego, CA, USA. ***, and ${ }^{* *}$ indicate $p<0.05,0.01$, and 0.001 , respectively.

\section{Results}

Within this study, natural materials from 17 plant species and three polypore species have been selected based on several criteria, primarily because of their long-standing traditional use in the field of inflammation and related areas, as well as anti-inflammatory effects described in the literature without in depth knowledge of their molecular mechanisms. Besides the 17 traditional herbal drugs, three polypore species were selected for the preparation of extracts, since they have been extensively used not only in TCM for the treatment of various ailments, but also for their health-promoting effects around the world [22]. A summary of the herbal and fungal materials used in this study, along with their traditional use and cognate pre-clinical and clinical studies, is given in Table 2.

Extracts of the selected herbal drugs and mushrooms were prepared to cope with a broad spectrum of metabolites endowed with drug like properties [11,12]. As a first assessment of their in vitro anti-inflammatory activity, we used a cell ELISA to screen these extracts for suppression of IL-1 stimulated E-selectin expression in human umbilical vein endothelial cells (HUVEC). The adhesion molecule E-selectin was chosen as a read-out, since it mediates one of the key steps in the inflammatory reaction, the initial weak adhesion ("rolling") of leucocytes on the endothelial wall. As shown in Figure 1, many of the tested extracts inhibited E-selectin expression in a dose-dependent manner. 
Table 2. Herbal and fungal materials with anti-inflammatory activity selected for this study, including their traditional application and reported in vitro and in vivo data; clinical evidence also includes studies not directly linked to inflammation.

\begin{tabular}{|c|c|c|c|}
\hline Herbal/Fungal Material & Traditional Use & In Vitro/In Vivo Studies & Clinical Studies \\
\hline $\begin{array}{l}\text { Herbs of Aquilegia vulgaris } \\
\text { (European columbine) }\end{array}$ & $\begin{array}{l}\text { Southern Europe, Asia and Africa; chronic skin } \\
\text { inflammation, liver and bile duct disorders, } \\
\text { jaundice [23-26]. }\end{array}$ & $\begin{array}{l}\text { Hepatoprotective }[24,26] \text { and antioxidant } \\
\text { effects }[23,25] .\end{array}$ & \\
\hline $\begin{array}{l}\text { Fruits of Azadirachta indica } \\
\text { (Neem fruits) }\end{array}$ & $\begin{array}{c}\text { Medicinal systems (Ayurveda [27,28], Unani and } \\
\text { Siddha [29]); as astringents and antihelmintic } \\
\text { agent [30]. }\end{array}$ & $\begin{array}{l}\text { Antioxidant and neuroprotective effecs [27]; } \\
\text { anti-bacterial [31], anti-nociceptive [32] and } \\
\text { osteogenic activities [33]. }\end{array}$ & \\
\hline $\begin{array}{l}\text { Roots and bark of Burkea } \\
\text { africana (Seringa tree) }\end{array}$ & $\begin{array}{l}\text { Sub-Saharan Africa; Pain (e.g., headache and } \\
\text { migraine), inflammation and as wound-healing } \\
\text { agents [34]. }\end{array}$ & Antioxidant [34] and anti-viral activites $[14,15]$. & \\
\hline $\begin{array}{l}\text { Herbs of Capsella bursa-pastoris } \\
\text { (Shepherd's purse) }\end{array}$ & $\begin{array}{l}\text { Traditional Chinese [35] and Korean folk medicine; } \\
\text { treatment of hypertension and edema [36]. }\end{array}$ & $\begin{array}{l}\text { Anti-inflammatory [35-37] and anti-viral } \\
\text { activities [15]. }\end{array}$ & $\begin{array}{l}\text { Reduced postpartum hemorrhage } \\
\text { bleeding in women [38]. }\end{array}$ \\
\hline $\begin{array}{l}\text { Fruits of Elettaria cardamomum } \\
\text { (Queen of spices) }\end{array}$ & $\begin{array}{l}\text { Ayurveda, Siddha and Unani [39]; Treatment of } \\
\text { asthma, teeth infections, cataracts, digestive and } \\
\text { kidney disorders [40]. }\end{array}$ & $\begin{array}{l}\text { Anti-inflammatory [41-43], anti-tumor [42,44], } \\
\text { anti-microbial [41,45] } \\
\text { activities;Immunomodulatory effects [42]. }\end{array}$ & $\begin{array}{l}\text { Improved parameters of inflammation } \\
\text { and oxidative stress in pre-diabetic } \\
\text { women [46]. }\end{array}$ \\
\hline $\begin{array}{l}\text { Herbs of Euphrasia officinalis } \\
\text { (Eyebright herb) }\end{array}$ & $\begin{array}{l}\text { Anthroposophical medicine [47]; conjunctivitis, } \\
\text { ophthalmia and ocular allergies [48] }\end{array}$ & $\begin{array}{c}\text { Anti-inflammatory activity }[37,49] ; \text { reduction of } \\
\text { UVB-induced cell death and increased } \\
\text { wound-healing ability [50]. }\end{array}$ & $\begin{array}{l}\text { Effective against allergic conjunctivitis } \\
\text { and conjunctivitis due to external } \\
\text { irritants or other causes [47]. }\end{array}$ \\
\hline $\begin{array}{l}\text { Fruit bodies of Fomitopsis } \\
\text { pinicola (Red banded polypore) }\end{array}$ & $\begin{array}{l}\text { Traditional Asian [51] and European medicine; } \\
\text { Nausea, headache and liver problems [22]. }\end{array}$ & $\begin{array}{c}\text { Anti-tumor [52,53], anti-oxidant [54], } \\
\text { anti-bacterial [55] and anti-inflammatory } \\
\text { activities }[56,57] .\end{array}$ & \\
\hline $\begin{array}{l}\text { Fruits of Forsythia suspensa } \\
\text { (Lian Qiao) }\end{array}$ & $\begin{array}{l}\text { Traditional Chinese Medicine (TCM) as } \\
\text { heart-clearing and detoxifying agent [58-60]. }\end{array}$ & $\begin{array}{l}\text { Anti-inflammatory }[59,61,62] \text {, anti-tumour }[59,63] \text {, } \\
\text { antioxidant }[64] \text { and anti-viral activities }[15,58,60] \text {. }\end{array}$ & \\
\hline $\begin{array}{l}\text { Fruit bodies of Gloeophyllum } \\
\text { odoratum (Anise mazegill) }\end{array}$ & Central Europe, Asia and North America $[17,65]$ & $\begin{array}{c}\text { Anti-influenza virus activity [17]; antioxidant [66] } \\
\text { and anti-cancer activities [67]; Thrombin } \\
\text { inhibition [68]. }\end{array}$ & \\
\hline $\begin{array}{l}\text { Female inflorescences of } \\
\text { Humulus lupulus (Hops) }\end{array}$ & $\begin{array}{l}\text { Management of sleeping disorders, as sedative, } \\
\text { and bitter stomachic }[69,70] \text {. }\end{array}$ & $\begin{array}{c}\text { Anti-inflammatory [71,72], antioxidant activities; } \\
\text { hepatoprotective [73] and osteoprotective } \\
\text { effects [74]. }\end{array}$ & $\begin{array}{l}\text { Effective against mild depression, } \\
\text { anxiety and stress [75]; reduction of early } \\
\text { postmenopausal symptoms (hot flashes, } \\
\text { sexual dysfunction, anxiety and } \\
\text { depression) [76]. }\end{array}$ \\
\hline
\end{tabular}


Table 2. Cont

\begin{tabular}{|c|c|c|c|}
\hline Herbal/Fungal Material & Traditional Use & In Vitro/In Vivo Studies & Clinical Studies \\
\hline $\begin{array}{l}\text { Leaves of Lactuca sativa } \\
\text { (Butterhead lettuce) }\end{array}$ & $\begin{array}{l}\text { Popular vegetable; Perception as "healthy" } \\
\text { food [77]. }\end{array}$ & Antioxidant properties $[78,79]$. & \\
\hline $\begin{array}{l}\text { Root bark of Morus alba } \\
\text { (Sang-Bai-Pi) }\end{array}$ & $\begin{array}{c}\text { TCM; Throat infections, asthma, fever and } \\
\text { inflammation [80]. }\end{array}$ & $\begin{array}{c}\text { Antioxidant, anti-cancer, } \\
\text { anti-inflammatory [80-82] and anti-viral } \\
\text { activities [15]. }\end{array}$ & \\
\hline $\begin{array}{l}\text { Roots and rhizome of } \\
\text { Peucedanum ostruthium } \\
\quad \text { (Masterwort) }\end{array}$ & $\begin{array}{c}\text { Austrian and Italian folk medicine; } \\
\text { gastro-intestinal, cardiovascular and respiratory } \\
\text { diseases }[37,83-85] .\end{array}$ & $\begin{array}{l}\text { Anti-inflammatory activity [37,85]; inhibition of } \\
\text { vascular smooth muscle cell proliferation [86]; } \\
\text { anti-amyloidogenic activity [84]. }\end{array}$ & \\
\hline $\begin{array}{l}\text { Fruits of Pimenta dioica } \\
\text { (Allspice) }\end{array}$ & $\begin{array}{l}\text { Jamaican [87] and Costa Rican medicine; } \\
\text { menopausal symptoms, dysmenorrhea and } \\
\text { dyspepsia [88]. }\end{array}$ & $\begin{array}{l}\text { Anti-oxidant [87], anti-diabetic effects [89] and } \\
\text { metabolic disorders via upregulation of TGR } \text { T }_{5} \text { [90]; } \\
\text { oestrogenic effects, inhibitory effect on breast and } \\
\text { gastric cancer cells [88]. }\end{array}$ & \\
\hline $\begin{array}{l}\text { Fruit bodies of Piptoporus } \\
\text { betulinus (Birch polypore) }\end{array}$ & $\begin{array}{l}\text { Central European folk medicine [22]; fatigue and } \\
\text { immune-enhancing properties [91] }\end{array}$ & $\begin{array}{l}\text { Anti-microbial [92], anti-inflammatory [91] and } \\
\text { anti-cancer activities [93]. }\end{array}$ & \\
\hline $\begin{array}{l}\text { Leaves of Plantago lanceolata } \\
\quad \text { (Ribwort plantain) }\end{array}$ & $\begin{array}{c}\text { Slovakian and Southeast European folk medicine; } \\
\text { gastric ulcers, respiratory infections and wound } \\
\text { healing }[94,95] .\end{array}$ & $\begin{array}{l}\text { Anti-inflammatory activities [36]; improved skin } \\
\text { wound healing [95]. }\end{array}$ & \\
\hline $\begin{array}{l}\text { Herbs of Potentilla aurea } \\
\quad \text { (Goldfinger herb) }\end{array}$ & $\begin{array}{l}\text { Southern and Central Europe [96-98], } \\
\text { homeopathic medications; diarrhea, diabetes } \\
\text { mellitus and inflammations [99]; }\end{array}$ & $\begin{array}{l}\text { Pancreatic lipase and } \alpha \text {-amylase inhibition [100]; } \\
\text { anti-urease activity [101] }\end{array}$ & \\
\hline $\begin{array}{l}\text { Heartwood of Pterocarpus } \\
\text { santalinus (Red sanders) }\end{array}$ & $\begin{array}{l}\text { India and Korea; Inflammation, mental } \\
\text { aberrations, cancer and ulcer [102,103] }\end{array}$ & $\begin{array}{l}\text { Antioxidant properties; anti-microbial [104] and } \\
\text { anti-inflammatory activities }[103,105] .\end{array}$ & \\
\hline $\begin{array}{l}\text { Herbs of Sida cordifolia (Indian } \\
\text { mallow) }\end{array}$ & $\begin{array}{l}\text { Indian, Chinese, African and Brazilian medicine; } \\
\text { skin diseases [106,107], inflammation of oral } \\
\text { mucosa, nasal congestion, asthmatic bronchitis } \\
\text { and rheumatism [108]. }\end{array}$ & $\begin{array}{l}\text { Anti-nociceptive [106], anti-inflammatory [109], } \\
\text { antioxidant activity and improved wound } \\
\text { healing [107]; Hepatoprotective effects [108]. }\end{array}$ & \\
\hline $\begin{array}{l}\text { Herbs of Verbena officinalis } \\
\text { (Vervain) }\end{array}$ & $\begin{array}{l}\text { European [110] and Chinese folk medicine; } \\
\text { rheumatism and bronchitis [111]. }\end{array}$ & $\begin{array}{l}\text { Anti-oxidant [112-114], anxiolytic, sedative, } \\
\text { anti-convulsant effects }[115,116] ; \\
\text { anti-inflammatory activities }[37,117] \text {. }\end{array}$ & $\begin{array}{l}\text { Ameliorative effect of chronic } \\
\text { generalized gingivitis [118]. }\end{array}$ \\
\hline
\end{tabular}


We selected the extract of $P$. ostruthium (PO) for further study based on the strength and robustness in repetitive experiments of its inhibitory effect. PO was characterized by PDA/ELSD-UPLC, and by means of UPLC-ESI-MS its main constituents could be dereplicated (Figure S1; Supplementary Materials). In Table S1 (Supplementary Materials) the results from the dereplication via literature search in SciFinder (accessed 2020/05/11) are presented. As a first step into the mechanistic investigation of E-selectin expression, we analyzed the mRNA levels after pre-incubation of HUVEC with different concentrations of PO (i.e., 50, 25 and $12 \mu \mathrm{g} / \mathrm{mL}$, respectively) and stimulation with $5 \mathrm{ng} / \mathrm{mL}$ IL-1. In addition, another adhesion molecule, VCAM-1, which mediates the firm adhesion of leucocytes to the endothelium, was analyzed. The choice of pre-incubation time was done based on previous experience with herbal extracts [20] and on experiments analyzing different times of pre-incubation depending on the concentration (Figure S2; Supplementary Materials). PO did not show toxicity at these concentrations (Figure S3; Supplementary Materials). As shown in Figure 2, PO strongly inhibited the expression of both adhesion molecules on the mRNA level in a dose-dependent manner, ranging from 50 to $15 \mu \mathrm{g} / \mathrm{mL}$.

A

E-selectin

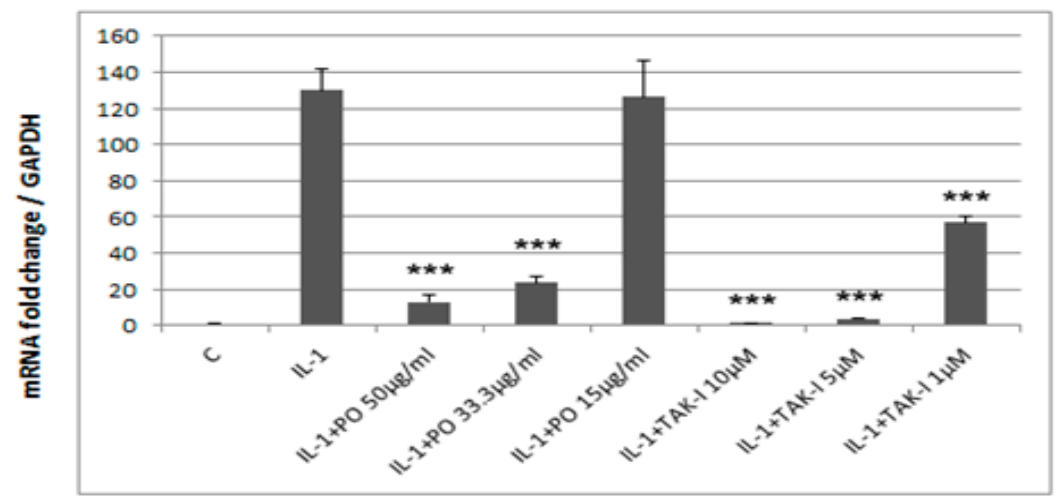

B VCAM-1

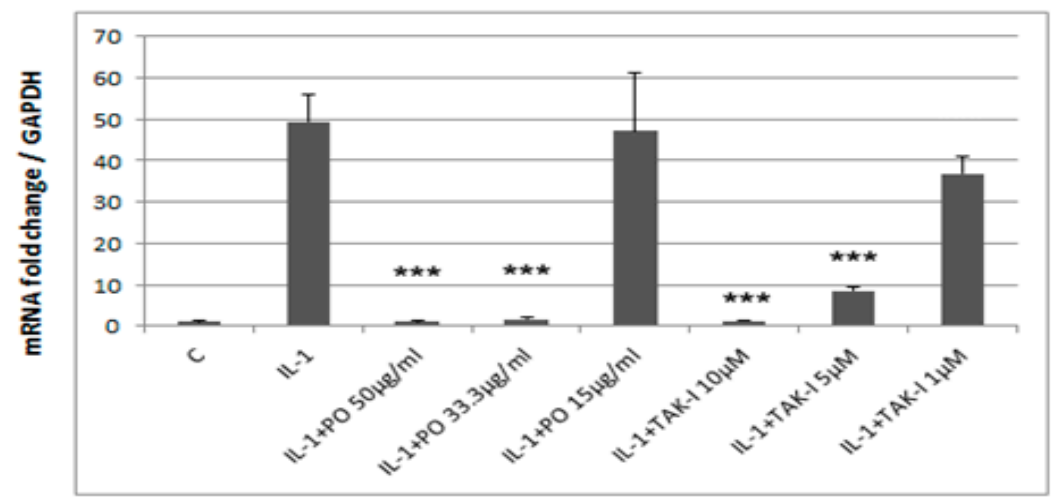

Figure 2. PO inhibits the expression of adhesion molecules in HUVEC. Post-confluent HUVEC were pre-incubated with different concentrations of PO for $30 \mathrm{~min}$ as indicated, then stimulated with IL-1 for $90 \mathrm{~min}$ and analyzed by qPCR for mRNA levels of (A) E-selectin and (B) VCAM-1. Values were normalized to GAPDH and are shown as fold change of IL-1 stimulation vs. unstimulated control. Triplicate samples were analyzed. ${ }^{* * *} p<0.001$ as compared to IL-1 stimulation. C: unstimulated control; TAK-I: positive control.

Since mRNA levels can be regulated on the level of transcription but also depend on other factors such as mRNA stability, we then determined whether the inhibition of E-selectin expression occurs on the transcriptional level. HUVEC were transfected with an E-selectin promoter luciferase reporter construct and, two days later, after reaching post-confluency, they were pre-incubated with PO and 
stimulated with IL-1. As shown in Figure 3A, PO inhibited the activity of the E-selectin promoter. Since the expression of E-selectin (and also VCAM-1) is dependent on NF- $\kappa \mathrm{B}$, we investigated whether PO might act via inhibition of this transcription factor. Therefore, HUVEC were transfected with a construct containing a multimerized NF- $\kappa B$ binding site driving the expression of a luciferase reporter gene, treated as above and analyzed for luciferase expression. PO diminished NF- $\mathrm{B}$ activity at all concentrations tested (although statistical significance was not reached; Figure 3B).

A

E-selectin-Luc

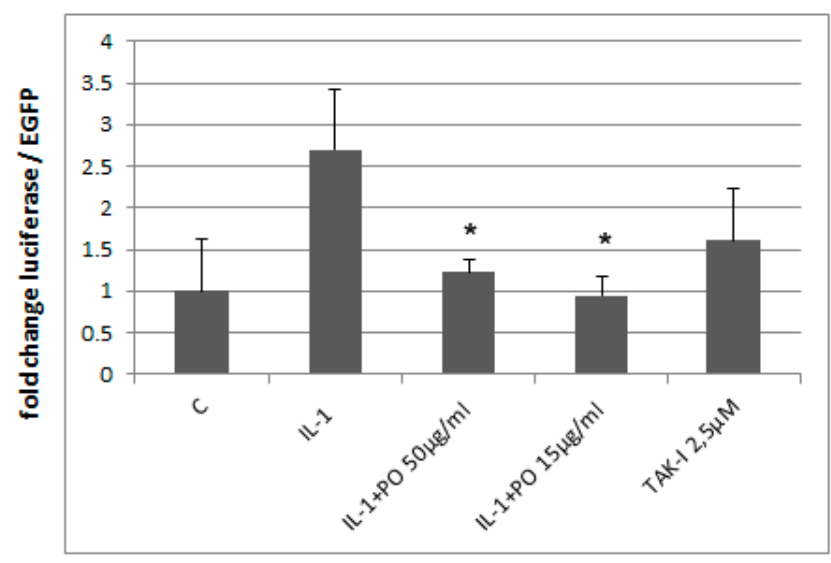

B

5x NF-kB-Luc

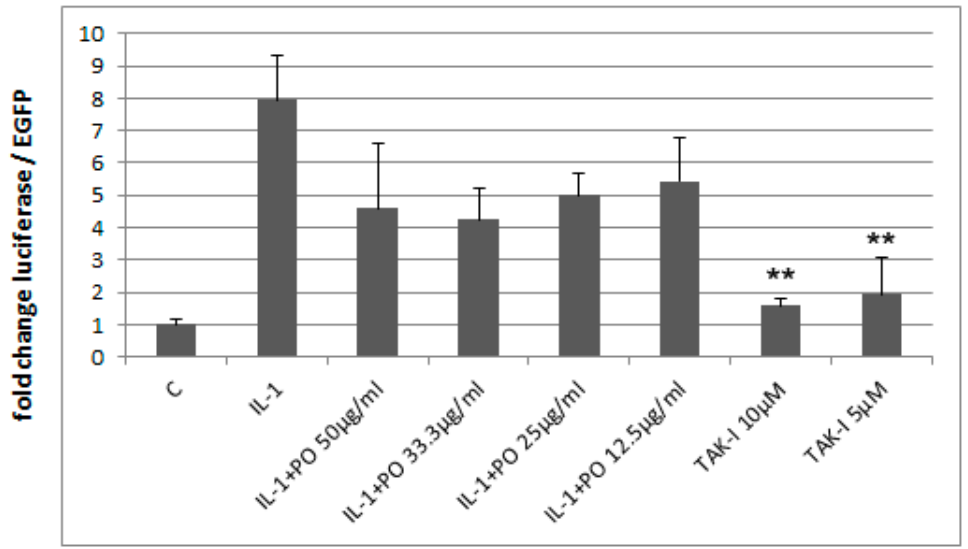

Figure 3. PO inhibits E-selectin promoter and NF- $\kappa B$ activity. HUVEC were transfected with either an E-selectin (A) or a NF- $\mathrm{BB}$ luciferase reporter construct (5xNF- $\mathrm{BB}$ luc; (B)) and EGFP as internal control, pretreated with PO (or TAK inhibitor as positive control) and stimulated with IL-1 as indicated. Luciferase levels were determined after $16 \mathrm{~h}$ and are shown as relative levels normalized to EGFP. Triplicate samples were analyzed. ${ }^{*} p<0.05,{ }^{* *} p<0.01$ as compared to IL-1 stimulation; C: unstimulated control.

Since one of the key steps in NF- $\mathrm{B}$ signaling is the phosphorylation and degradation of its inhibitor $\mathrm{I}_{\kappa} \mathrm{B} \alpha$, which takes place within minutes after stimulation and is followed by re-synthesis that

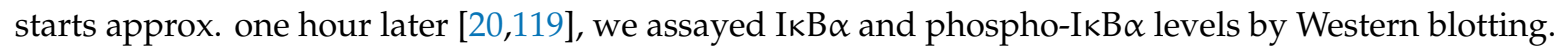
HUVEC were pre-incubated and stimulated as above, except that the times of stimulation were adjusted to assay for both the early and late events. As shown in Figure 4, IкB $\alpha$ was degraded within 10 min following IL-1 stimulation and re-synthesized at $90 \mathrm{~min}$; in PO-treated cells, degradation was slightly delayed, but re-synthesis entirely inhibited. Accordingly, and in contrast to IL-1 stimulation alone, I $\mathrm{K} \mathrm{B} \alpha$ phosphorylation was still visible at $10 \mathrm{~min}$ in IL-1+PO-treated cells, suggesting a 
delay in degradation. Previously, the group of D. Baltimore described "oscillations" of NF- $\mathrm{B}$ nuclear-cytoplasmic translocation due to several rounds of degradation and re-synthesis of IkB $\alpha$ as well as other I $\kappa B$ species [120]. Whereas this phenomenon can be seen best in T cells where multiple waves can be observed, endothelial cells also show at least one additional wave of NF- $\mathrm{kB}$ nuclear translocation and the associated $\mathrm{I} \kappa \mathrm{B} \alpha$ phosphorylation and degradation. In our experiments, this second wave is indicated by the re-appearance of $\mathrm{pI} \kappa \mathrm{B} \alpha$ between 30 and $90 \mathrm{~min}$; it is lacking in PO (as well as in TAK-I) pretreated cells. In addition, the phosphorylation of IKKs in the activation loop, which is a measurement for their activity [121], did not show, besides a weak prolongation, a pronounced difference between IL-1- and IL-1+PO-treated HUVEC; together, these data indicate that the initial steps of activation, namely IKK activation and I $\mathrm{K} B \alpha$ phosphorylation/degradation, are weakly affected, whereas the later steps are predominant. This suggests that in HUVEC, PO displays two types of activity towards NF- $\mathrm{kB}$, one (weaker) that affects the initial steps of activation, and a second, more pronounced one that is directed towards a downstream part of the NF- $\mathrm{kB}$ signaling cascade.
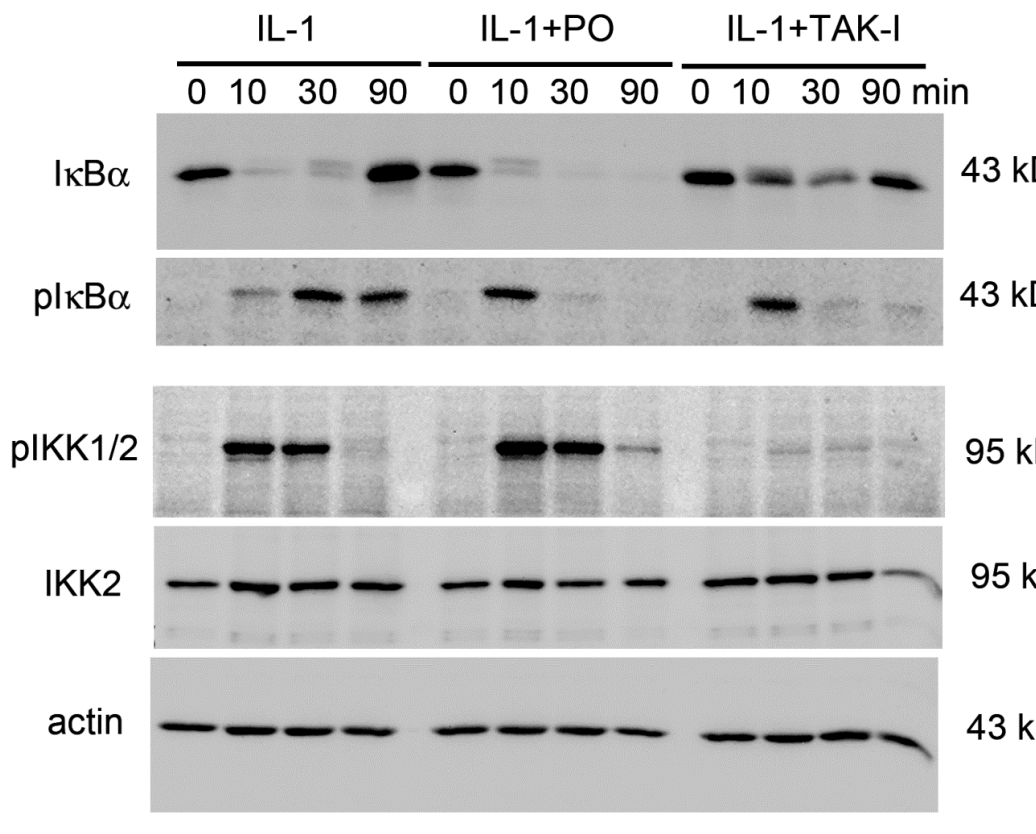

$95 \mathrm{kD}$

$95 \mathrm{kD}$

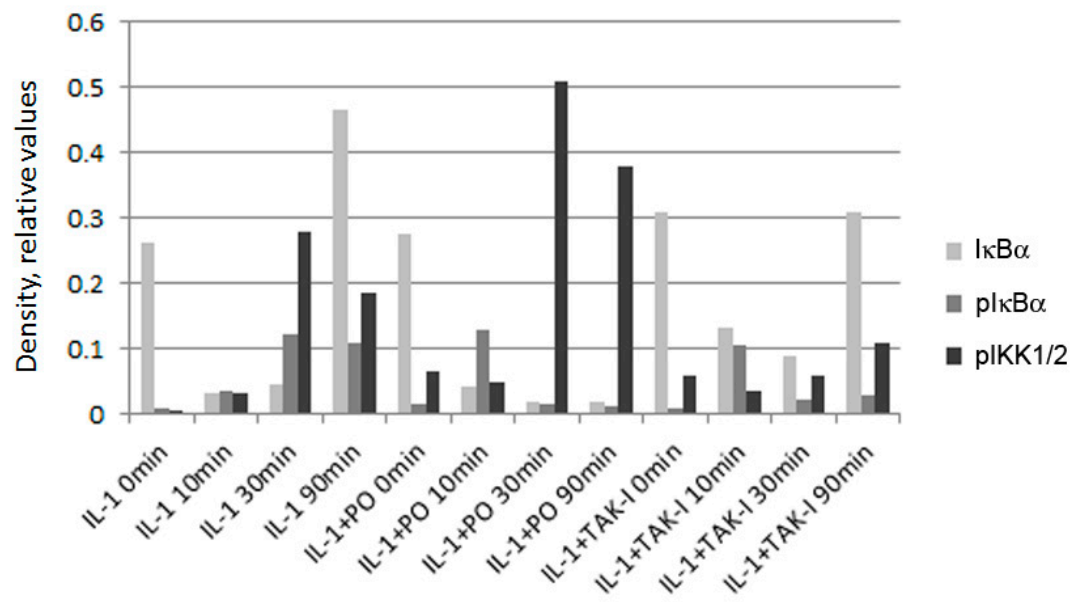

Figure 4. PO affects $I \kappa B \alpha$ degradation and IKK phosphorylation. Post-confluent HUVEC were pre-incubated with $50 \mu \mathrm{g} / \mathrm{mL}$ of PO for $30 \mathrm{~min}$, then stimulated with $5 \mathrm{ng} / \mathrm{mL}$ IL-1 for $90 \mathrm{~min}$ and probed for IKB $\alpha$, phospho-IкB $\alpha$, and phospho-IKK1/2; IKK2 and B-actin served as loading controls, the TAK-inhibitor $(5 \mu \mathrm{M})$ as control for inhibition. IкB $\alpha / \mathrm{pI \kappa B} \alpha$ and IKK2/pIKKs/actin were analyzed on separate gels. A densitometric quantification is shown below. 
In order to further analyze the mechanism and kinetics of $\mathrm{PO}$ on NF- $\mathrm{B}$ activation, we performed immunostaining to asses NF- $\kappa B$ nuclear translocation. HUVEC were pre-treated as above, and stimulated with $5 \mathrm{ng} / \mathrm{mL} \mathrm{IL}-1$ for 15, 30, and $90 \mathrm{~min}$. As shown in Figure 5A, the p65 subunit of NF-kB (RelA) translocated into the nucleus within $15 \mathrm{~min}$, whereas this was delayed in PO-treated cells (Figure 5B). The later time points were not affected. This confirmed that PO does have an effect on an early step of NF- $\mathrm{kB}$ signaling, but that additional mechanisms at later stages of the signaling cascade are operative, that add to the later events such as the lack of IkB $\alpha$ re-synthesis, the overall diminished activity in the reporter gene assay and, as a result, diminished adhesion molecule expression.

A

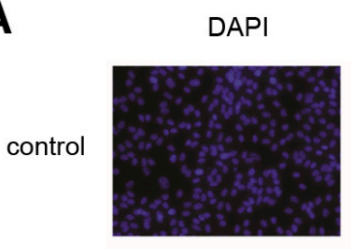

IL-1 $15 \min$
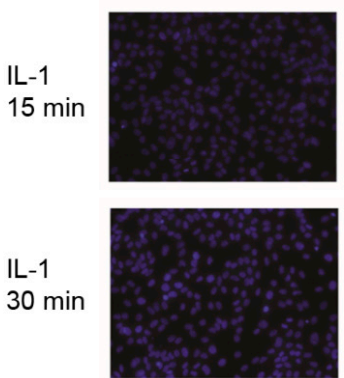

IL-1 $90 \mathrm{~min}$

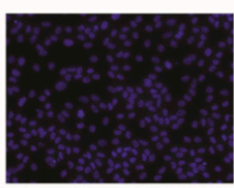

B
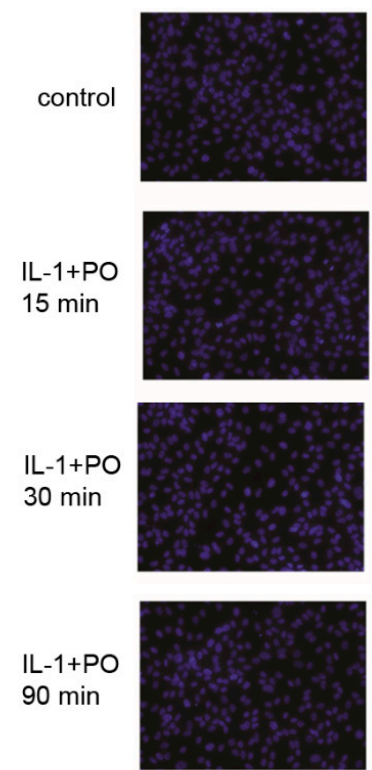

p65/RelA
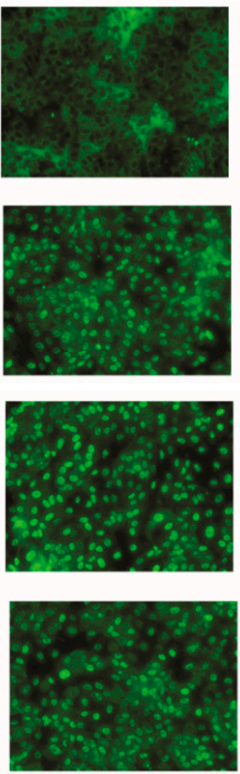

p65/RelA
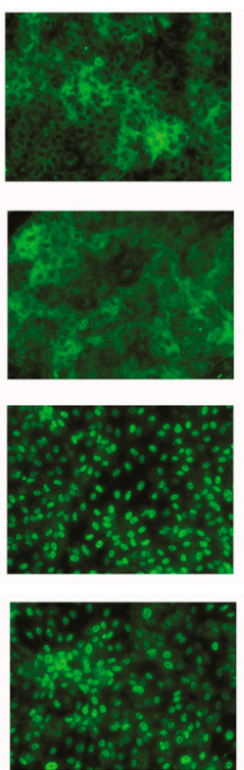

actin
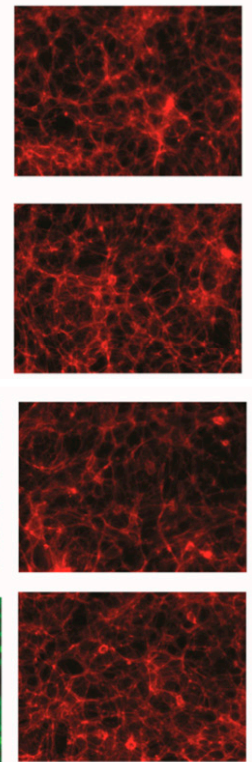

actin
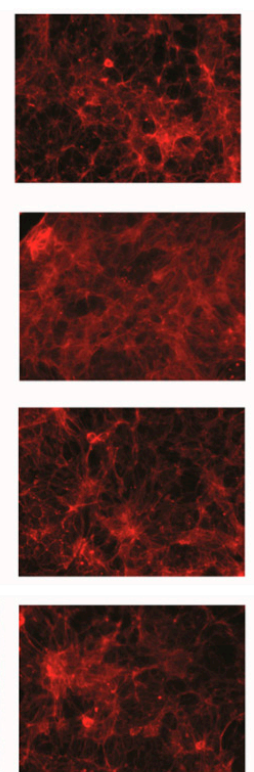

merged
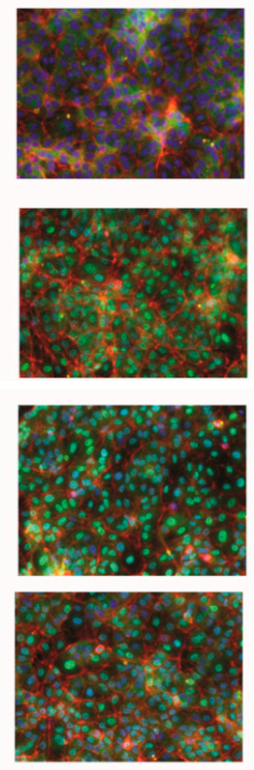

merged
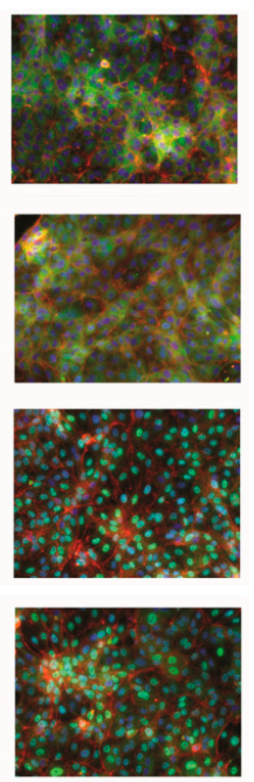

Figure 5. PO delays nuclear translocation of NF-кB. HUVEC were either (A) stimulated with $5 \mathrm{ng} / \mathrm{mL}$ IL-1 alone for the indicated times or (B) pre-treated for $30 \mathrm{~min}$ with $50 \mathrm{ng} / \mathrm{mL}$ PO before IL-1 stimulation, and immunostained for the p65/RelA subunit of NF-kB (green) and actin (red). Nuclei were stained with DAPI (blue). Merged pictures are shown on the right. 


\section{Discussion}

Based on the long-standing traditional use of masterwort in the Alpine region and further studies in the scientific literature, but limited knowledge of its mode of action, we selected PO from a set of extracts with anti-inflammatory activity for further analysis in our model system. Peucedanum (Apiaceae) comprises approximately 120 species in several continents including Europe, Africa, Asia, and North America. Many of these have been used in traditional medicine for the treatment of a variety of diverse disorders, e.g., pyrexia, cardiovascular, gastrointestinal or neurological diseases. This is likely due to the broad spectrum of constituents, including various coumarins, phenolic acids, amines, glycosides, flavonoids, diterpenes and components of their essential oils [122].

Regarding inflammatory conditions, mainly P. praeruptorium, P. japonicum, and P. decursivum have been subject to more intense research, often in the context of airway inflammation [123-126]. PO contains a variety of furanocoumarins including imperatorin and iso-imperatorin, pimpinellin and iso-pimpinellin, oxypeucedanin and derivatives, ostruthol, peucedocoumarin III, coumarines such as ostruthin and the chromones peucenin and alsaticol [83,122]. PO extracts and isolated compounds have been found to inhibit the PIK3/Akt/mTor pathway [127], prevent SMC proliferation [86], and display anti-Amyloid\$1-42 aggregation [84], anti-mycobacterial and anti-insecticidal activities [128]. Anti-inflammatory and immunomodulatory activities were attributed to the coumarin family member osthole and its derivatives [129]. Moreover, Hiermann and Schantl reported antiphlogistic and anti-pyretic effects as well as the inhibition of cyclooxygenase and 5-lipoxygenase by PO extracts and isolated coumarin compounds [85].

Only recently, we identified and isolated several bioactive compounds from PO by applying a novel biochemometric approach named Eliciting Nature's Activities (ELINA; $[18,130]$ ) with an NF-kB reporter-gene assay plus two assays for E-selectin and VCAM-1 as biological read-out. However, the anti-inflammatory activity could only partially recovered (as compared to the total extract) by the combination of imperatorin and peucenin as a mixture, suggesting additional combinatorial effects [18].

Therefore, we here investigated the anti-inflammatory activity of the total extract in more detail and provide first insight into its molecular mechanism(s) of action. In IL-1 stimulated endothelial cells, PO suppressed the expression of the adhesion molecule E-selectin. Inhibition was found on both the mRNA and protein levels. Moreover, PO inhibited the activity of E-selectin on the transcriptional level, as demonstrated by reporter gene experiments (Figure 3A). Moreover, since E-selectin transcription is dependent on NF- $\mathrm{KB}$, we also investigated the activity of $\mathrm{PO}$ on this transcription factor by reporter gene analysis and demonstrate that PO strongly inhibited NF- $\mathrm{kB}$ activity (Figure $3 \mathrm{~B}$ ).

One of the key steps in the NF- $\mathrm{KB}$ signaling pathway is the phosphorylation and ubiquitin-dependent degradation of the inhibitor $\operatorname{I} \mathrm{B} \alpha$, which forms a cytoplasmic complex with NF- $\mathrm{KB}$ p65/p50 to prevent its nuclear translocation. In contrast to IL-1 alone, IL-1 in combination with PO treated cells showed a slight delay in IKB $\alpha$ phosphorylation and degradation, and a total lack of $\mathrm{I} \kappa \mathrm{B} \alpha$ re-synthesis (which is NF- $\kappa \mathrm{B}-\mathrm{dependent).} \mathrm{The} \mathrm{re-appearance} \mathrm{of} \mathrm{phospho-I \kappa B} \alpha$ specific species at 30 and 90 min after treatment, indicative of a second wave of NF-kB activation, is lacking in PO-treated cells. This second wave has been observed in other cells, and was most pronounced in T cells where even multiple oscillations can occur that result from repeated degradation and resynthesis in the $\mathrm{NF}-\kappa \mathrm{B} / \mathrm{I} \kappa \mathrm{B} \alpha$ (and other I $\kappa \mathrm{Bs}$ such as $-\mathrm{B}$ and $-\mathrm{e}$ ) system [120]. It has been speculated that these have differential effects on the expression of NF- $\mathrm{kB}$-dependent genes [131].

To investigate upstream events, we additionally probed for activation of IKK2, the main kinase responsible for $I \kappa B \alpha$ phosphorylation and found that, in line with the $I \kappa B \alpha$ data, its activation was only slightly inhibited. In contrast, our positive control (5Z)-7-oxozeaenol that inhibits TAK1, a kinase that together with its co-activators TAB1 and $-2 / 3$ transmits the signal from the IL-1 (and also TNF) receptor to activate IKK2, completely prevented IKK2 phosphorylation and subsequent IKB $\alpha$ degradation. Together, it can be concluded that PO displays a weak effect on either IKK2 or an upstream signaling molecule, but that additional more downstream effects have to be operative. 
This was subsequently confirmed by immunofluorescence studies, which showed a delay in nuclear translocation of NF- $\mathrm{kB}$ (Figure 5, compare 15 min timepoint between IL-1 (A) and IL-1+PO, (B)). Surprisingly, however, at 30 and $90 \mathrm{~min}, \mathrm{NF}-\mathrm{kB}$ nuclear translocation was indistinguishable between these conditions. This suggests that, at these timepoints, although NF- $\mathrm{KB}$ resides in the nucleus, its activity must be impaired by other mechanisms. At this point, we can only speculate about their nature, but several possibilities have been described, e.g., post-translational mechanisms such as phosphorylation, acetylation, S-nitrosylation that affect either DNA-binding or transactivation, miRNAs, or the crosstalk with other signaling pathways such as PPAR $\alpha$ and $-\mathrm{B}$, ATF3, or STAT3. These will be the subject of further investigations.

\section{Conclusions}

The anti-inflammatory activity that has been ascribed to PO by traditional medicine and previous reports could be substantiated in this study and attributed to the inhibition of gene expression of the pro-inflammatory cell adhesion molecules E-selectin and VCAM-1. Thereby, PO acts by inhibiting predominantly, but probably not exclusively, the activity of NF- $\mathrm{kB}$. Although this inhibition does involve, to a certain degree, the initial steps of activation including nuclear translocation, a major part of the inhibitory activity takes place at later stages. From a therapeutic point of view NF-kB inhibition holds promise for the treatment of a wide variety of mainly inflammation-related disorders, but also others such as, e.g., therapy-resistance in cancer. However, most cognate NF- $\kappa B$ inhibitors target signaling molecules that act early in the pathway such as IKK2, TAK1, or IKB $\alpha$ (through inhibition of ubiquitination). Our observation that $\mathrm{PO}$ also inhibits later stages of activation could be of interest, since it suggests that it affects signaling molecules which are distinct from cognate drug targets. Identification of these may open the way for the identification of lead compounds and, subsequently, novel drugs.

Supplementary Materials: The following are available online at http://www.mdpi.com/2218-273X/10/9/1215/s1, Figure S1: UPLC of PO showing the (A) total ion chromatogram (TIC, positive mode) containing compounds 1-8, (B) ELSD and (C) PDA 210 nm chromatogram; Figure S2: Pre-incubation time with PO affects its inhibitory potential; Figure S3: Cytotoxicity of PO; Table S1: Results from the dereplication of PO via literature search; Table S2: Primers for real-time PCR.

Author Contributions: Conceptualization, J.M.R., and R.d.M.; investigation, C.L., J.Z., J.S.; writing-original draft preparation, R.d.M., J.M.R.; writing-review and editing, all authors; visualization, C.L., J.Z., J.S., R.d.M.; supervision, R.d.M., J.M.R.; project administration, R.d.M., J.M.R. All authors have read and agreed to the published version of the manuscript.

Funding: This research received no external funding.

Conflicts of Interest: The authors declare no conflict of interest.

\section{References}

1. Mayer, H.; Bilban, M.; Kurtev, V.; Gruber, F.; Wagner, O.; Binder, B.R.; De Martin, R. Deciphering regulatory patterns of inflammatory gene expression from interleukin-1-stimulated human endothelial cells. Arterioscler. Thromb. Vasc. Biol. 2004, 24, 1192-1198. [CrossRef]

2. De Martin, R.; Hoeth, M.; Hofer-Warbinek, R.; Schmid, J.A. The transcription factor NF-kappa B and the regulation of vascular cell function. Arterioscler. Thromb. Vasc. Biol. 2000, 20, e83-e88.

3. Fiordelisi, A.; Iaccarino, G.; Morisco, C.; Coscioni, E.; Sorriento, D. NFkappaB is a key player in the crosstalk between inflammation and cardiovascular diseases. Int. J. Mol. Sci. 2019, 20, 1599. [CrossRef]

4. Renner, F.; Schmitz, M.L. Autoregulatory feedback loops terminating the NF-kappaB response. Trends Biochem. Sci. 2009, 34, 128-135. [CrossRef]

5. Winsauer, G.; de Martin, R. Resolution of inflammation: Intracellular feedback loops in the endothelium. Thromb. Haemost. 2007, 97. [CrossRef]

6. Sakamoto, Y.; Kanatsu, J.; Toh, M.; Naka, A.; Kondo, K.; Iida, K. The Dietary Isoflavone Daidzein Reduces Expression of Pro-Inflammatory Genes through PPARalpha/gamma and JNK Pathways in Adipocyte and Macrophage Co-Cultures. PLoS ONE 2016, 11, e0149676. [CrossRef] 
7. Schmitz, M.L.; Baeuerle, P.A. The p65 subunit is responsible for the strong transcription activating potential of NF-kappa B. EMBO J. 1991, 10, 3805-3817. [CrossRef]

8. Zhong, L.; Simard, M.J.; Huot, J. Endothelial microRNAs regulating the NF-kappaB pathway and cell adhesion molecules during inflammation. FASEB J. 2018, 32, 4070-4084. [CrossRef]

9. Newman, D.J.; Cragg, G.M. Natural products as sources of new drugs over the nearly four decades from 01/1981 to 09/2019. J. Nat. Prod. 2020, 83, 770-803. [CrossRef]

10. Gerlach, S.; Saukel, J.; Kubelka, W. Pflanzen in der österreichischen Volksmedizin. Die "VOLKSMED-Datenbank”. Sci. Pharm. 2006, 74, S36.

11. Kratz, J.M.; Mair, C.E.; Oettl, S.K.; Saxena, P.; Scheel, O.; Schuster, D.; Hering, S.; Rollinger, J.M. hERG channel blocking ipecac alkaloids identified by combined in silico-In vitro screening. Planta Med. 2016, 82, 1009-1015. [CrossRef]

12. Camp, D.; Davis, R.A.; Campitelli, M.; Ebdon, J.; Quinn, R.J. Drug-like properties: Guiding principles for the design of natural product libraries. J. Nat. Prod. 2012, 75, 72-81. [CrossRef]

13. Tu, Y.; Jeffries, C.; Ruan, H.; Nelson, C.; Smithson, D.; Shelat, A.A.; Brown, K.M.; Li, X.C.; Hester, J.P.; Smillie, T.; et al. Automated high-throughput system to fractionate plant natural products for drug discovery. J. Nat. Prod. 2010. [CrossRef]

14. Mair, C.E.; Grienke, U.; Wilhelm, A.; Urban, E.; Zehl, M.; Schmidtke, M.; Rollinger, J.M. Anti-influenza triterpene saponins from the bark of Burkea africana. J. Nat. Prod. 2018, 81, 515-523. [CrossRef]

15. Grienke, U.; Mair, C.E.; Kirchmair, J.; Schmidtke, M.; Rollinger, J.M. Discovery of bioactive natural products for the treatment of acute respiratory infections-An integrated approach *. Planta Med. 2018, 84, 684-695. [CrossRef]

16. Zwirchmayr, J.; Kirchweger, B.; Lehner, T.; Tahir, A.; Pretsch, D.; Rollinger, J.M. A robust and miniaturized screening platform to study natural products affecting metabolism and survival in Caenorhabditis elegans. Sci. Rep. 2020. [CrossRef]

17. Grienke, U.; Zwirchmayr, J.; Peintner, U.; Urban, E.; Zehl, M.; Schmidtke, M.; Rollinger, J.M. Lanostane triterpenes from Gloeophyllum odoratum and their anti-influenza effects. Planta Med. 2019, 85, 195-202. [CrossRef]

18. Zwirchmayr, J.; Grienke, U.; Hummelbrunner, S.; Seigner, J.; de Martin, R.; Dirsch, V.M.; Rollinger, J.M. A biochemometric approach for the identification of in vitro anti-inflammatory constituents in masterwort. Biomolecules 2020, 28, 679. [CrossRef]

19. Hoeth, M.; Niederleithner, H.; Hofer-Warbinek, R.; Bilban, M.; Mayer, H.; Resch, U.; Lemberger, C.; Wagner, O.; Hofer, E.; Petzelbauer, P.; et al. The transcription factor SOX18 regulates the expression of matrix metalloproteinase 7 and guidance molecules in human endothelial cells. PLoS ONE 2012, 7, e30982. [CrossRef]

20. Seigner, J.; Junker-Samek, M.; Plaza, A.; D’Urso, G.; Masullo, M.; Piacente, S.; Holper-Schichl, Y.M.; de Martin, R. A Symphytum officinale Root Extract Exerts Anti-inflammatory Properties by Affecting Two Distinct Steps of NF-kappaB Signaling. Front. Pharmacol. 2019, 10, 289. [CrossRef]

21. Seigner, J.; Basilio, J.; Resch, U.; de Martin, R. CD40L and TNF both activate the classical NF-kB pathway, which is not required for the CD40L induced alternative pathway in endothelial cells. Biochem. Biophys. Res. Commun. 2017, 495, 1389-1394. [CrossRef] [PubMed]

22. Grienke, U.; Zoll, M.; Peintner, U.; Rollinger, J.M. European medicinal polypores-a modern view on traditional uses. J. Ethnopharmacol. 2014, 154, 564-583. [CrossRef] [PubMed]

23. Abdel-Aziem, S.H.; El-Nekeety, A.A.; Barakat, I.A.; Mohamed, M.I.; Abdel-Wahhab, M.A. Aquilegia vulgaris extract protects against the oxidative stress and the mutagenic effects of cadmium in Balb/c mice. Exp. Toxicol. Pathol. 2011, 63, 337-344. [CrossRef]

24. Jodynis-Liebert, J.; Adamska, T.; Ewertowska, M.; Bylka, W.; Matławska, I. Aquilegia vulgaris extract attenuates carbon tetrachloride-induced liver fibrosis in rats. Exp. Toxicol. Pathol. 2009, 61, 443-451. [CrossRef]

25. Hassan, A.M.; Mohamed, S.R.; El-Nekeety, A.A.; Hassan, N.S.; Abdel-Wahhab, M.A. Aquilegia vulgaris L. extract counteracts oxidative stress and cytotoxicity of fumonisin in rats. Toxicon 2010, 56, 8-18. [CrossRef]

26. Adamska, T.; Mlynarczyk, W.; Jodynis-Liebert, J.; Bylka, W.; Matlawska, I. Hepatoprotective effect of the extract and isocytisoside from Aquilegia vulgaris. Phytother. Res. 2003, 17, 691-696. [CrossRef]

27. Subapriya, R.; Nagini, S. Medicinal properties of Neem leaves: A review. Currrent Med. Chem. Anti Cancer Agents 2005, 5, 149-156. [CrossRef] 
28. Xiang, X.; Wu, L.; Mao, L.; Liu, Y. Antioxidative and antiapoptotic neuroprotective effects of Azadirachta indica in Parkinsoninduced functional damage. Mol. Med. Rep. 2018, 17, 7959-7965. [CrossRef]

29. Patel, S.M.; Nagulapalli Venkata, K.C.; Bhattacharyya, P.; Sethi, G.; Bishayee, A. Potential of neem (Azadirachta indica L.) for prevention and treatment of oncologic diseases. Semin. Cancer Biol. 2016, 40-41, 100-115. [CrossRef]

30. Hao, F.; Kumar, S.; Yadav, N.; Chandra, D. Neem components as potential agents for cancer prevention and treatment. Biochim. Biophys. Acta Rev. Cancer 2014, 1846, 247-257. [CrossRef]

31. Joy Sinha, D.; Nandha, K.D.S.; Jaiswal, N.; Vasudeva, A.; Prabha Tyagi, S.; Pratap Singh, U. Antibacterial Effect of Azadirachta indica (Neem) or Curcuma longa (Turmeric) against Enterococcus faecalis Compared with That of 5\% Sodium Hypochlorite or 2\% Chlorhexidine in vitro. Bull. Tokyo Dent. Coll 2017, 58, 103-109. [CrossRef]

32. Batista, F.L.A.; Lima, L.M.G.; Abrante, I.A.; de Araujo, J.I.F.; Batista, F.L.A.; Abrante, I.A.; Magalhaes, E.A.; de Lima, D.R.; Lima, M.; do Prado, B.S.; et al. Antinociceptive activity of ethanolic extract of Azadirachta indica A. Juss (Neem, Meliaceae) fruit through opioid, glutamatergic and acid-sensitive ion pathways in adult zebrafish (Danio rerio). Biomed. Pharmacother. 2018, 108, 408-416. [CrossRef]

33. Kushwaha, P.; Khedgikar, V.; Haldar, S.; Gautam, J.; Mulani, F.A.; Thulasiram, H.V.; Trivedi, R. Azadirachta indica triterpenoids promote osteoblast differentiation and mineralization in vitro and in vivo. Bioorg. Med. Chem. Lett. 2016, 26, 3719-3724. [CrossRef]

34. Mathisen, E.; Diallo, D.; Andersen, O.M.; Malterud, K.E. Antioxidants from the bark of Burkea africana, an African medicinal plant. Phytother. Res. 2002, 16, 148-153. [CrossRef]

35. Peng, J.; Hu, T.; Li, J.; Du, J.; Zhu, K.; Cheng, B.; Li, K. Shepherd's Purse Polyphenols Exert Its Anti-Inflammatory and Antioxidative Effects Associated with Suppressing MAPK and NF-kappaB Pathways and Heme Oxygenase-1 Activation. Oxid. Med. Cell. Longev. 2019, 2019, 7202695. [CrossRef]

36. Cha, J.M.; Kim, D.H.; Lee, T.H.; Subedi, L.; Kim, S.Y.; Lee, K.R. Phytochemical constituents of Capsella bursa-pastoris and their anti-inflammatory activity. Nat. Prod. Sci. 2018, 24, 132-138. [CrossRef]

37. Vogl, S.; Picker, P.; Mihaly-Bison, J.; Fakhrudin, N.; Atanasov, A.G.; Heiss, E.H.; Wawrosch, C.; Reznicek, G.; Dirsch, V.M.; Saukel, J.; et al. Ethnopharmacological in vitro studies on Austria's folk medicine-an unexplored lore in vitro anti-inflammatory activities of 71 Austrian traditional herbal drugs. J. Ethnopharmacol. 2013, 149, 750-771. [CrossRef]

38. Ghalandari, S.; Kariman, N.; Sheikhan, Z.; Mojab, F.; Mirzaei, M.; Shahrahmani, H. Effect of hydroalcoholic extract of Capsella bursa pastoris on early postpartum hemorrhage: A clinical trial study. J. Altern. Complement. Med. 2017, 23, 794-799. [CrossRef]

39. Nadkarni, K.M. Indian Materia Medica: With Ayurvedic, Unani-Tibbi, Siddha, Allopathic, Homeopathic, Naturopathic $\mathcal{E}$ Home Remedies, Appendices E Indexes; Popular Prakashan Private Ltd.: Mumbai, India, 1996; Volume 1.

40. Gilani, A.H.; Jabeen, Q.; Khan, A.; Shah, A.J. Gut modulatory, blood pressure lowering, diuretic and sedative activities of cardamom. J. Ethnopharmacol. 2008, 115, 463-472. [CrossRef]

41. Souissi, M.; Azelmat, J.; Chaieb, K.; Grenier, D. Antibacterial and anti-inflammatory activities of cardamom (Elettaria cardamomum) extracts: Potential therapeutic benefits for periodontal infections. Anaerobe 2019, 61, 102089. [CrossRef]

42. Majdalawieh, A.F.; Carr, R.I. In vitro investigation of the potential immunomodulatory and anti-cancer activities of black pepper (Piper nigrum) and cardamom (Elettaria cardamomum). J. Med. Food 2010, 13, 371-381. [CrossRef]

43. Das, I.; Acharya, A.; Berry, D.L.; Sen, S.; Williams, E.; Permaul, E.; Sengupta, A.; Bhattacharya, S.; Saha, T. Antioxidative effects of the spice cardamom against non-melanoma skin cancer by modulating nuclear factor erythroid-2-related factor 2 and NF-kappaB signalling pathways. Br. J. Nutr. 2012, 108, 984-997. [CrossRef]

44. Qiblawi, S.; Al-Hazimi, A.; Al-Mogbel, M.; Hossain, A.; Bagchi, D. Chemopreventive effects of cardamom (Elettaria cardamomum L.) on chemically induced skin carcinogenesis in Swiss albino mice. J. Med. Food 2012, 15, 576-580. [CrossRef]

45. Mutlu-Ingok, A.; Karbancioglu-Guler, F. Cardamom, cumin, and dill weed essential oils: Chemical compositions, antimicrobial activities, and mechanisms of action against campylobacter spp. Molecules 2017, 22, 1191. [CrossRef] 
46. Kazemi, S.; Yaghooblou, F.; Siassi, F.; Rahimi Foroushani, A.; Ghavipour, M.; Koohdani, F.; Sotoudeh, G. Cardamom supplementation improves inflammatory and oxidative stress biomarkers in hyperlipidemic, overweight, and obese pre-diabetic women: A randomized double-blind clinical trial. J. Sci. Food Agric. 2017, 97, 5296-5301. [CrossRef]

47. Stoss, M.; Michels, C.; Peter, E.; Beutke, R.; Gorter, R.W. Prospective cohort trial of Euphrasia single-dose eye drops in conjunctivitis. J. Altern. Complement. Med. 2000, 6, 499-508. [CrossRef]

48. Liu, Y.; Hwang, E.; Ngo, H.T.T.; Perumalsamy, H.; Kim, Y.J.; Li, L.; Yi, T.-H. Protective effects of Euphrasia officinalis Extract against Ultraviolet B-Induced Photoaging in Normal Human Dermal Fibroblasts. Int. J. Mol. Sci. 2018, 19, 3327. [CrossRef]

49. Paduch, R.; Woźniak, A.; Niedziela, P.; Rejdak, R. Assessment of eyebright (Euphrasia Officinalis L.) extract activity in relation to human corneal cells using in vitro tests. Balk. Med. J. 2014, 31, 29-36. [CrossRef]

50. Bigagli, E.; Cinci, L.; D'Ambrosio, M.; Luceri, C. Pharmacological activities of an eye drop containing Matricaria chamomilla and Euphrasia officinalis extracts in UVB-induced oxidative stress and inflammation of human corneal cells. J. Photochem. Photobiol. B Biol. 2017, 173, 618-625. [CrossRef]

51. Hao, L.; Sheng, Z.; Lu, J.; Tao, R.; Jia, S. Characterization and antioxidant activities of extracellular and intracellular polysaccharides from Fomitopsis pinicola. Carbohydr. Polym. 2016, 141, 54-59. [CrossRef]

52. Wu, H.-T.; Lu, F.-H.; Su, Y.-C.; Ou, H.-Y.; Hung, H.-C.; Wu, J.-S.; Yang, Y.-C.; Chang, C.-J. In vivo and in vitro anti-tumor effects of fungal extracts. Molecules 2014, 19, 2546-2556. [CrossRef]

53. Bhattarai, G.; Lee, Y.-H.; Lee, N.-H.; Lee, I.-K.; Yun, B.-S.; Hwang, P.-H.; Yi, H.-K. Fomitoside-K from Fomitopsis nigra Induces Apoptosis of Human Oral Squamous Cell Carcinomas (YD-10B) via Mitochondrial Signaling Pathway. Biol. Pharm. Bull. 2012, 35, 1711-1719. [CrossRef]

54. Choi, D.; Park, S.-S.; Ding, J.-L.; Cha, W.-S. Effects of Fomitopsis pinicola extracts on antioxidant and antitumor activities. Biotechnol. Bioprocess. Eng. 2007, 12, 516. [CrossRef]

55. Hwang, C.H.; Jaki, B.U.; Klein, L.L.; Lankin, D.C.; McAlpine, J.B.; Napolitano, J.G.; Fryling, N.A.; Franzblau, S.G.; Cho, S.H.; Stamets, P.E.; et al. Chlorinated Coumarins from the Polypore Mushroom Fomitopsis officinalis and Their Activity against Mycobacterium tuberculosis. J. Nat. Prod. 2013, 76, 1916-1922. [CrossRef]

56. Yoshikawa, K.; Inoue, M.; Matsumoto, Y.; Sakakibara, C.; Miyataka, H.; Matsumoto, H.; Arihara, S. Lanostane Triterpenoids and Triterpene Glycosides from the Fruit Body of Fomitopsis pinicola and Their Inhibitory Activity against COX-1 and COX-2. J. Nat. Prod. 2005, 68, 69-73. [CrossRef]

57. Tai, S.-H.; Kuo, P.-C.; Hung, C.-C.; Lin, Y.-H.; Hwang, T.-L.; Lam, S.H.; Kuo, D.-H.; Wu, J.-B.; Hung, H.-Y.; $\mathrm{Wu}, \mathrm{T}$.-S. Bioassay-guided purification of sesquiterpenoids from the fruiting bodies of Fomitopsis pinicola and their anti-inflammatory activity. RSC Adv. 2019, 9, 34184-34195. [CrossRef]

58. Zhao, L.; Xiang, K.-L.; Liu, R.-X.; Xie, Z.-P.; Zhang, S.-M.; Dai, S.-J. Anti-inflammatory and anti-viral labdane diterpenoids from the fruits of Forsythia suspensa. Bioorg. Chem. 2020, 96, 103651. [CrossRef]

59. Zhao, L.; Yan, X.; Shi, J.; Ren, F.; Liu, L.; Sun, S.; Shan, B. Ethanol extract of Forsythia suspensa root induces apoptosis of esophageal carcinoma cells via the mitochondrial apoptotic pathway. Mol. Med. Rep. 2015, 11, 871-880. [CrossRef] [PubMed]

60. Ko, H.-C.; Wei, B.-L.; Chiou, W.-F. Dual regulatory effect of plant extracts of Forsythia suspense on RANTES and MCP-1 secretion in influenza A virus-infected human bronchial epithelial cells. J. Ethnopharmacol. 2005, 102, 418-423. [CrossRef]

61. Kim, M.-S.; Na, H.-J.; Han, S.-W.; Jin, J.-S.; Song, U.-Y.; Lee, E.-J.; Song, B.-K.; Hong, S.-H.; Kim, H.-M. Forsythia fructus Inhibits the Mast-Cell-Mediated Allergic Inflammatory Reactions. Inflammation 2003, 27, 129-135. [CrossRef]

62. Zhong, W.; Wu, Y.; Xie, X.; Zhou, X.; Wei, M.; Soromou, L.-W.; Ci, X.; Wang, D. Phillyrin attenuates LPS-induced pulmonary inflammation via suppression of MAPK and NF-kB activation in acute lung injury mice. Fitoterapia 2013, 90, 132-139. [CrossRef] [PubMed]

63. Bao, J.; Liu, F.; Zhang, C.; Wang, K.; Jia, X.; Wang, X.; Chen, M.; Li, P.; Su, H.; Wang, Y.; et al. Anti-melanoma activity of Forsythiae Fructus aqueous extract in mice involves regulation of glycerophospholipid metabolisms by UPLC/Q-TOF MS-based metabolomics study. Sci. Rep. 2016, 6, 39415. [CrossRef] [PubMed]

64. Zhao, P.; Piao, X.; Pan, L.; Zeng, Z.; Li, Q.; Xu, X.; Wang, H. Forsythia suspensa extract attenuates lipopolysaccharide-induced inflammatory liver injury in rats via promoting antioxidant defense mechanisms. Anim. Sci. J. 2017, 88, 873-881. [CrossRef] [PubMed] 
65. Kahlos, K. Gloeophyllum odoratum (Brown Rot Fungus); In vitro culture, growth, and production of volatiles, sterols and triterpenes. In Biotechnology in Agriculture and Forestry 37: Medicinal and Aromativ Plants IX; Bajaj, Y.P.S., Ed.; Springer: Berlin/Heidelberg, Germany; New York, NY, USA, 1996; Volume 1, pp. 144-164.

66. Tel-Cayan, G. Phenolic profiles, antioxidant, and anticholinesterase activities of three Gloeophyllum species with chemometric approach. J. Food Biochem. 2019, 43, e12790. [CrossRef] [PubMed]

67. Grienke, U.; Kaserer, T.; Kirchweger, B.; Lambrinidis, G.; Kandel, R.T.; Foster, P.A.; Schuster, D.; Mikros, E.; Rollinger, J.M. Steroid sulfatase inhibiting lanostane triterpenes - Structure activity relationship and in silico insights. Bioorg. Chem. 2020, 95, 103495. [CrossRef]

68. Francesca, C.; Vittorio, L.; Marko, A.; Paolo, M.; Marina, Z.; Andrej, P.; Bojan, D. Triterpenes from Gloeophyllum odoratum as Potential Leads Towards Potent Thrombin Inhibitors. Lett. Drug Des. Discov. 2010, 7, 521-527. [CrossRef]

69. Zanoli, P.; Zavatti, M. Pharmacognostic and pharmacological profile of Humulus lupulus L. J. Ethnopharmacol. 2008, 116, 383-396. [CrossRef]

70. Štulíková, K.; Karabín, M.; Nešpor, J.; Dostálek, P. Therapeutic Perspectives of 8-Prenylnaringenin, a potent phytoestrogen from hops. Molecules 2018, 23, 660. [CrossRef]

71. Sangiovanni, E.; Fumagalli, M.; Santagostini, L.; Forino, M.; Piazza, S.; Colombo, E.; Taglialatela-Scafati, O.; Fico, G.; Dell'Agli, M. A bio-guided assessment of the anti-inflammatory activity of hop extracts (Humulus lupulus L. cv. Cascade) in human gastric epithelial cells. J. Funct. Foods 2019, 57, 95-102. [CrossRef]

72. Schink, A.; Neumann, J.; Leifke, A.L.; Ziegler, K.; Froehlich-Nowoisky, J.; Cremer, C.; Thines, E.; Weber, B.; Poeschl, U.; Schuppan, D.; et al. Screening of herbal extracts for TLR2- and TLR4-dependent anti-inflammatory effects. PLoS ONE 2018, 13, e0203907/1-e0203907/27. [CrossRef]

73. Zhou, D.; Wang, C.; Li, X.; Zhao, Y.; Jing, J.; Ma, Y.; Li, J.; Wei, X.; Li, N. Dietary functional flavonoids as natural hepatoprotective agents against acute liver injury from hop (Humulus lupulus L.). J. Funct. Foods 2018, 45, 471-479. [CrossRef]

74. Xia, T.; Lin, L.; Zhang, Q.; Jiang, Y.; Li, C.; Liu, X.; Qin, L.; Xin, H. Humulus lupulus L. Extract prevents ovariectomy-induced osteoporosis in mice and regulates activities of osteoblasts and osteoclasts. Chin. J. Integr. Med. 2019. [CrossRef]

75. Kyrou, I.; Christou, A.; Panagiotakos, D.; Stefanaki, C.; Skenderi, K.; Katsana, K.; Tsigos, C. Effects of a hops (Humulus lupulus L.) dry extract supplement on self-reported depression, anxiety and stress levels in apparently healthy young adults: A randomized, placebo-controlled, double-blind, crossover pilot study. Hormones 2017, 16, 171-180. [CrossRef] [PubMed]

76. Aghamiri, V.; Mirghafourvand, M.; Mohammad-Alizadeh-Charandabi, S.; Nazemiyeh, H. The effect of Hop (Humulus lupulus L.) on early menopausal symptoms and hot flashes: A randomized placebo-controlled trial. Complement. Ther. Clin. Pract. 2016, 23, 130-135. [CrossRef]

77. Llorach, R.; Martínez-Sánchez, A.; Tomás-Barberán, F.A.; Gil, M.I.; Ferreres, F. Characterisation of polyphenols and antioxidant properties of five lettuce varieties and escarole. Food Chem. 2008, 108, 1028-1038. [CrossRef] [PubMed]

78. Durazzo, A.; Azzini, E.; Lazzé, M.C.; Raguzzini, A.; Pizzala, R.; Maiani, G.; Palomba, L.; Maiani, G. Antioxidants in Italian Head Lettuce (Lactuca sativa var. capitata L.) Grown in Organic and Conventional Systems under Greenhouse Conditions. J. Food Biochem. 2014, 38, 56-61. [CrossRef]

79. Moreno-Escamilla, J.O.; Alvarez-Parrilla, E.; de la Rosa, L.A.; Núñez-Gastélum, J.A.; González-Aguilar, G.A.; Rodrigo-García, J. Effect of Different Elicitors and Preharvest Day Application on the Content of Phytochemicals and Antioxidant Activity of Butterhead Lettuce (Lactuca sativa var. capitata) Produced under Hydroponic Conditions. J. Agric. Food Chem. 2017, 65, 5244-5254. [CrossRef] [PubMed]

80. Culenova, M.; Sychrova, A.; Hassan, S.T.S.; Berchova-Bimova, K.; Svobodova, P.; Helclova, A.; Michnova, H.; Hosek, J.; Vasilev, H.; Suchy, P.; et al. Multiple In vitro biological effects of phenolic compounds from Morus alba root bark. J. Ethnopharmacol. 2020, 248, 112296. [CrossRef]

81. Chung, K.O.; Kim, B.Y.; Lee, M.H.; Kim, Y.R.; Chung, H.Y.; Park, J.H.; Moon, J.O. In-vitro and in-vivo anti-inflammatory effect of oxyresveratrol from Morus alba L. J. Pharm. Pharmacol. 2003, 55, 1695-1700. [CrossRef]

82. Lim, H.J.; Jin, H.-G.; Woo, E.-R.; Lee, S.K.; Kim, H.P. The root barks of Morus alba and the flavonoid constituents inhibit airway inflammation. J. Ethnopharmacol. 2013, 149, 169-175. [CrossRef] 
83. Vogl, S.; Zehl, M.; Picker, P.; Urban, E.; Wawrosch, C.; Reznicek, G.; Saukel, J.; Kopp, B. Identification and quantification of coumarins in Peucedanum ostruthium (L.) Koch by HPLC-DAD and HPLC-DAD-MS. J. Agric. Food Chem. 2011, 59, 4371-4377. [CrossRef] [PubMed]

84. Palmioli, A.; Bertuzzi, S.; De Luigi, A.; Colombo, L.; La Ferla, B.; Salmona, M.; De Noni, I.; Airoldi, C. bioNMR-based identification of natural anti-Abeta compounds in Peucedanum ostruthium. Bioorg. Chem. 2019, 83, 76-86. [CrossRef] [PubMed]

85. Hiermann, A.; Schantl, D. Antiphlogistic and antipyretic activity of Peucedanum ostruthium. Planta Med. 1998, 64, 400-403. [CrossRef] [PubMed]

86. Joa, H.; Vogl, S.; Atanasov, A.G.; Zehl, M.; Nakel, T.; Fakhrudin, N.; Heiss, E.H.; Picker, P.; Urban, E.; Wawrosch, C.; et al. Identification of ostruthin from Peucedanum ostruthium rhizomes as an inhibitor of vascular smooth muscle cell proliferation. J. Nat. Prod. 2011, 74, 1513-1516. [CrossRef]

87. Padmakumari, K.P.; Sasidharan, I.; Sreekumar, M.M. Composition and antioxidant activity of essential oil of pimento (Pimenta dioica (L) Merr.) from Jamaica. Nat. Prod. Res. 2011, 25, 152-160. [CrossRef]

88. Doyle, B.J.; Lawal, T.O.; Locklear, T.D.; Hernandez, L.; Perez, A.L.; Patel, U.; Patel, S.; Mahady, G.B. Isolation and identification of three new chromones from the leaves of Pimenta dioica with cytotoxic, oestrogenic and anti-oestrogenic effects. Pharm. Biol. 2018, 56, 235-244. [CrossRef]

89. Pereira, A.S.P.; Banegas-Luna, A.J.; Pena-Garcia, J.; Perez-Sanchez, H.; Apostolides, Z. Evaluation of the anti-diabetic activity of some common herbs and spices: Providing new insights with inverse virtual screening. Molecules 2019, 24, 4030. [CrossRef]

90. Ladurner, A.; Zehl, M.; Grienke, U.; Hofstadler, C.; Faur, N.; Pereira, F.C.; Berry, D.; Dirsch, V.M.; Rollinger, J.M. Allspice and clove as source of triterpene acids activating the $\mathrm{G}$ protein-coupled bile acid receptor TGR5. Front. Pharmacol. 2017, 8, 468/1-468/13. [CrossRef]

91. Kamo, T.; Asanoma, M.; Shibata, H.; Hirota, M. Anti-inflammatory Lanostane-Type Triterpene Acids from Piptoporus betulinus. J. Nat. Prod. 2003, 66, 1104-1106. [CrossRef]

92. Tohtahon, Z.; Xue, J.; Han, J.; Liu, Y.; Hua, H.; Yuan, T. Cytotoxic lanostane triterpenoids from the fruiting bodies of Piptoporus betulinus. Phytochemistry 2017, 143, 98-103. [CrossRef]

93. Khalilov, Q.; Li, L.; Liu, Y.; Tohtahon, Z.; Chen, X.; Aisa, H.A.; Yuan, T. Piptolinic acids F-J, five new lanostane-type triterpenoids from Piptoporus betulinus. Nat. Prod. Res. 2019, 33, 3044-3051. [CrossRef] [PubMed]

94. Jaric, S.; Kostic, O.; Mataruga, Z.; Pavlovic, D.; Pavlovic, M.; Mitrovic, M.; Pavlovic, P. Traditional wound-healing plants used in the Balkan region (Southeast Europe). J. Ethnopharmacol. 2018, 211, 311-328. [CrossRef] [PubMed]

95. Kovac, I.; Durkac, J.; Holly, M.; Jakubcova, K.; Perzelova, V.; Mucaji, P.; Svajdlenka, E.; Sabol, F.; Legath, J.; Belak, J.; et al. Plantago lanceolata L. water extract induces transition of fibroblasts into myofibroblasts and increases tensile strength of healing skin wounds. J. Pharm. Pharmacol. 2015, 67, 117-125. [CrossRef] [PubMed]

96. Muhlemann, H. Falsification of herba Potentillae aureae L. Pharm. Acta Helv. 1938, 13, 67-70.

97. Schappi, B. Growth dynamics and population development in an alpine grassland under elevated $\mathrm{CO}_{2}$. Oecologia 1996, 106, 93-99. [CrossRef]

98. Kołodziejek, J.; Patykowski, J.; Wala, M. Dormancy, germination, and sensitivity to salinity stress in five species of Potentilla (Rosaceae). Botany 2019, 97, 452-462. [CrossRef]

99. Tomczyk, M.; Latté, K.P. Potentilla-A review of its phytochemical and pharmacological profile. J. Ethnopharmacol. 2009, 122, 184-204. [CrossRef]

100. Buchholz, T.; Melzig, M.F. Medicinal Plants Traditionally Used for Treatment of Obesity and Diabetes Mellitus-Screening for Pancreatic Lipase and $\alpha$-Amylase Inhibition. Phytother. Res. 2016, 30, 260-266. [CrossRef]

101. Hřibová, P.; Khazneh, E.; Žemlička, M.; Švajdlenka, E.; Ghoneim, M.M.; Elokely, K.M.; Ross, S.A. Antiurease activity of plants growing in the Czech Republic. Nat. Prod. Res. 2014, 28, 868-873. [CrossRef]

102. Kwon, H.J.; Hong, Y.K.; Kim, K.H.; Han, C.H.; Cho, S.H.; Choi, J.S.; Kim, B.-W. Methanolic extract of Pterocarpus santalinus induces apoptosis in HeLa cells. J. Ethnopharmacol. 2006, 105, 229-234. [CrossRef]

103. Wu, S.-F.; Hwang, T.-L.; Chen, S.-L.; Wu, C.-C.; Ohkoshi, E.; Lee, K.-H.; Chang, F.-R.; Wu, Y.-C. Bioactive components from the heartwood of Pterocarpus santalinus. Bioorg. Med. Chem. Lett. 2011, 21, 5630-5632. [CrossRef] [PubMed] 
104. Challa, C.S.; Lokesh, T.; Nayakanti, D.; Varadacharyulu, N.C. Phytochemical and anti-microbial study of Pterocarpus santalinus Linn Heartwood. Res. J. Life Sci. Bioinf. Pharm. Chem. Sci. 2019, 5, 451-464. [CrossRef]

105. Dhande, P.P.; Gupta, A.O.; Jain, S.; Dawane, J.S. Anti-inflammatory and analgesic activities of topical formulations of Pterocarpus santalinus powder in rat model of chronic inflammation. J. Clin. Diagn. Res. 2017, 11, Ff01-Ff04. [CrossRef] [PubMed]

106. Bonjardim, L.R.; Silva, A.M.; Oliveira, M.G.; Guimaraes, A.G.; Antoniolli, A.R.; Santana, M.F.; Serafini, M.R.; Santos, R.C.; Araujo, A.A.; Estevam, C.S.; et al. Sida cordifolia leaf extract reduces the orofacial nociceptive response in mice. Phytother. Res. 2011, 25, 1236-1241. [CrossRef] [PubMed]

107. Kumar, S.; Lakshmi, P.K.; Sahi, C.; Pawar, R.S. Sida cordifolia accelerates wound healing process delayed by dexamethasone in rats: Effect on ROS and probable mechanism of action. J. Ethnopharmacol. 2019, 235, 279-292. [CrossRef]

108. Rejitha, S.; Prathibha, P.; Indira, M. Amelioration of alcohol-induced hepatotoxicity by the administration of ethanolic extract of Sida cordifolia Linn. Br. J. Nutr. 2012, 108, 1256-1263. [CrossRef]

109. Martins, C.A.F.; Campos, M.L.; Irioda, A.C.; Stremel, D.P.; Trindade, A.; Pontarolo, R. Anti-Inflammatory effect of Malva sylvestris, Sida cordifolia, and Pelargonium graveolens is related to inhibition of prostanoid production. Molecules 2017, 22, 1883. [CrossRef]

110. Fateh, A.H.; Mohamed, Z.; Chik, Z.; Alsalahi, A.; Md Zain, S.R.; Alshawsh, M.A. Mutagenicity and genotoxicity effects of Verbena officinalis leaves extract in Sprague-Dawley Rats. J. Ethnopharmacol. 2019, 235, 88-99. [CrossRef]

111. Shu, J.; Chou, G.; Wang, Z. Two new iridoids from Verbena officinalis L. Molecules 2014, 19, $10473-10479$. [CrossRef]

112. Casanova, E.; García-Mina, J.M.; Calvo, M.I. Antioxidant and antifungal activity of Verbena officinalis L. Leaves. Plant. Foods Hum. Nutr. 2008, 63, 93-97. [CrossRef]

113. Rehecho, S.; Hidalgo, O.; García-Iñiguez de Cirano, M.; Navarro, I.; Astiasarán, I.; Ansorena, D.; Cavero, R.Y.; Calvo, M.I. Chemical composition, mineral content and antioxidant activity of Verbena officinalis L. LWT Food Sci. Technol. 2011, 44, 875-882. [CrossRef]

114. Calvo, M.I. Anti-inflammatory and analgesic activity of the topical preparation of Verbena officinalis L. J. Ethnopharmacol. 2006, 107, 380-382. [CrossRef] [PubMed]

115. Khan, A.W.; Khan, A.U.; Ahmed, T. Anticonvulsant, Anxiolytic, and Sedative Activities of Verbena officinalis. Front. Pharmacol. 2016, 7, 499. [CrossRef] [PubMed]

116. Rashidian, A.; Kazemi, F.; Mehrzadi, S.; Dehpour, A.R.; Mehr, S.E.; Rezayat, S.M. Anticonvulsant effects of aerial parts of Verbena officinalis extract in mice: Involvement of benzodiazepine and opioid receptors. J. Evid. Based Complement. Altern. Med. 2017, 22, 632-636. [CrossRef] [PubMed]

117. Deepak, M.; Handa, S.S. Antiinflammatory activity and chemical composition of extracts of Verbena officinalis. Phytother. Res. 2000, 14, 463-465. [CrossRef]

118. Grawish, M.E.; Anees, M.M.; Elsabaa, H.M.; Abdel-Raziq, M.S.; Zedan, W. Short-term effects of Verbena officinalis Linn decoction on patients suffering from chronic generalized gingivitis: Double-blind randomized controlled multicenter clinical trial. Quintessence Int. 2016, 47, 491-498. [CrossRef]

119. Mechtcheriakova, D.; Schabbauer, G.; Lucerna, M.; Clauss, M.; De Martin, R.; Binder, B.R.; Hofer, E. Specificity, diversity, and convergence in VEGF and TNF- $\alpha$ signaling events leading to tissue factor upregulation via EGR-1 in endothelial cells. FASEB J. 2001, 15. [CrossRef]

120. Hoffmann, A.; Levchenko, A.; Scott, M.L.; Baltimore, D. The IkappaB-NF-kappaB signaling module: Temporal control and selective gene activation. Science 2002, 298, 1241-1245. [CrossRef]

121. Delhase, M.; Hayakawa, M.; Chen, Y.; Karin, M. Positive and negative regulation of IkappaB kinase activity through IKKbeta subunit phosphorylation. Science 1999, 284, 309-313. [CrossRef]

122. Sarkhail, P. Traditional uses, phytochemistry and pharmacological properties of the genus Peucedanum: A review. J. Ethnopharmacol. 2014, 156, 235-270. [CrossRef]

123. Chun, J.M.; Lee, A.R.; Kim, H.S.; Lee, A.Y.; Gu, G.J.; Moon, B.C.; Kwon, B.I. Peucedanum japonicum extract attenuates allergic airway inflammation by inhibiting Th2 cell activation and production of pro-inflammatory mediators. J. Ethnopharmacol. 2018, 211, 78-88. [CrossRef] [PubMed]

124. Xiong, Y.Y.; Wang, J.S.; Wu, F.H.; Li, J.; Kong, L.Y. The effects of (+/-)-Praeruptorin A on airway inflammation, remodeling and transforming growth factor-beta1/Smad signaling pathway in a murine model of allergic asthma. Int. Immunopharmacol. 2012, 14, 392-400. [CrossRef] [PubMed] 
125. Xiong, Y.Y.; Wu, F.H.; Wang, J.S.; Li, J.; Kong, L.Y. Attenuation of airway hyperreactivity and T helper cell type 2 responses by coumarins from Peucedanum praeruptorum Dunn in a murine model of allergic airway inflammation. J. Ethnopharmacol. 2012, 141, 314-321. [CrossRef] [PubMed]

126. Yu, P.J.; Ci, W.; Wang, G.F.; Zhang, J.Y.; Wu, S.Y.; Xu, W.; Jin, H.; Zhu, Z.G.; Zhang, J.J.; Pang, J.X.; et al. Praeruptorin A inhibits lipopolysaccharide-induced inflammatory response in murine macrophages through inhibition of NF-kappaB pathway activation. Phytother. Res. 2011, 25, 550-556. [CrossRef] [PubMed]

127. Du, M.; Sun, Z.; Lu, Y.; Li, Y.Z.; Xu, H.R.; Zeng, C.Q. Osthole inhibits proliferation and induces apoptosis in BV-2 microglia cells in kainic acid-induced epilepsy via modulating PI3K/AKt/mTOR signalling way. Pharm. Biol. 2019, 57, 238-244. [CrossRef]

128. Hadacek, F.; Muller, C.; Werner, A.; Greger, H.; Proksch, P. Analysis, isolation and insecticidal activity of linear furanocoumarins and other coumarin derivatives from Peucedanum (Apiaceae: Apioideae). J. Chem. Ecol. 1994, 20, 2035-2054. [CrossRef]

129. Zimecki, M.; Artym, J.; Cisowski, W.; Mazol, I.; Włodarczyk, M.; Gleńsk, M. Immunomodulatory and anti-inflammatory activity of selected osthole derivatives. Z. Fur Naturforsch. Sect. C J. Biosci. 2009, 64, 361-368. [CrossRef]

130. Grienke, U.; Foster, P.A.; Zwirchmayr, J.; Tahir, A.; Rollinger, J.M.; Mikros, E. (1)H NMR-MS-based heterocovariance as a drug discovery tool for fishing bioactive compounds out of a complex mixture of structural analogues. Sci. Rep. 2019, 9, 11113. [CrossRef]

131. Werner, S.L.; Kearns, J.D.; Zadorozhnaya, V.; Lynch, C.; O’Dea, E.; Boldin, M.P.; Ma, A.; Baltimore, D.; Hoffmann, A. Encoding NF-kappaB temporal control in response to TNF: Distinct roles for the negative regulators IkappaBalpha and A20. Genes Dev. 2008, 22, 2093-2101. [CrossRef]

(C) 2020 by the authors. Licensee MDPI, Basel, Switzerland. This article is an open access article distributed under the terms and conditions of the Creative Commons Attribution (CC BY) license (http://creativecommons.org/licenses/by/4.0/). 